NBER WORKING PAPER SERIES

\title{
INVESTMENT-BASED UNDERPERFORMANCE FOLLOWING SEASONED EQUITY OFFERINGS
}

\author{
Evgeny Lyandres \\ Le Sun \\ Lu Zhang \\ Working Paper 11459 \\ http://www.nber.org/papers/w11459
NATIONAL BUREAU OF ECONOMIC RESEARCH 1050 Massachusetts Avenue
Cambridge, MA 02138
June 2005

Lyandres: Room 240-MS 531, 6100 Main Street, Houston, TX 77005, tel: (713) 348-4708, fax: (713) 3486296, and email: lyandres@rice.edu. Sun: 500 Wilson Blvd, Rochester, NY 14627, tel: (585) 275-4318, and email: lesun@simon.rochester.edu. Zhang: Carol Simon Hall 3-160B, 500 Wilson Blvd, Simon School of Business, University of Rochester, Rochester, NY 14627, tel (585) 273-1140, and email: zhanglu@simon.rochester.edu. We thank Espen Eckbo and Jeff Wurgler for helpful comments and we thank Sagit Harel and Haukur Skúlason for excellent research assistance. The views expressed herein are those of the author(s) and do not necessarily reflect the views of the National Bureau of Economic Research.

(C2005 by Evgeny Lyandres, Le Sun, and Lu Zhang. All rights reserved. Short sections of text, not to exceed two paragraphs, may be quoted without explicit permission provided that full credit, including (C) notice, is given to the source. 
Investment-Based Underperformance Following Seasoned Equity Offerings

Evgeny Lyandres, Le Sun, Lu Zhang

NBER Working Paper No. 11459

June 2005, Revised February 2006

JEL No. E22, E44, G12, G14, G24, G31, G32

\section{ABSTRACT}

Adding a return factor based on capital investment into standard, calendar-time factor regressions makes underperformance following seasoned equity offerings largely insignificant and reduces its magnitude by $37-46 \%$. The reason is that issuers invest more than nonissuers matched on size and book-to-market. Moreover, the low-minus-high investment-to-asset factor earns a significant average return of $0.37 \%$ per month. Our evidence suggests that the underperformance results from the negative investment-expected return relation, as predicted by Carlson, Fisher, and Giammarino (2005).

Evgeny Lyandres

Jones School of Management

Rice University

Room 240-MS 531, 6100 Main Street

Houston, TX 77005

lyandres@rice.edu

Le Sun

Simon School

University of Rochester

Carol Simon Hall 4-328

Rochester, NY 14627

lesun@simon.rochester.edu

Lu Zhang

Simon School

University of Rochester

Carol Simon Hall 4-328

Rochester, NY 14627

and NBER

zhanglu@simon.rochester.edu 


\section{Introduction}

We study long-term underperformance following seasoned equity offerings (SEOs). Our central finding is that adding a return factor based on capital investment into the CAPM and the Fama and French (1993) three-factor model makes the underperformance largely insignificant and reduces its magnitude by around $40 \%$.

Two forces drive this result. First, equity issuers invest much more than matching nonissuers with similar size and book-to-market. In the year preceding the SEOs, the median investment-to-asset ratio of issuers is on average 0.090 from 1970 to 2003. In contrast, this ratio is 0.054 for matching nonissuers, about $40 \%$ lower. Similar dispersion in investment-toasset ratios persists for two years and does not disappear until about five years after equity issuance. Second, capital investment is negatively related to future average returns. We construct a zero-cost portfolio by buying stocks with the lowest $30 \%$ investment-to-asset ratios and selling stocks with the highest $30 \%$ investment-to-asset ratios. This portfolio, which we call the investment factor, earns an average return of $0.37 \%$ per month with a highly significant $t$-statistic of 4.35 , controlling for size and book-to-market.

Our evidence lends support to the predictions of Carlson, Fisher, and Giammarino (2005) and Zhang (2005). In their real options model, Carlson et al. argue that firms have expansion options and assets in place prior to equity issuance. This composition is levered and risky. If capital investment is financed by equity, then risk must decrease because investment in effect extinguishes the risky growth options. Using a different but equivalent argument from the $Q$-theory, Zhang derives the negative relation between investment and future average returns. Intuitively, investment increases with the net present value (NPV) of future cash flows generated by one additional unit of capital (e.g., Brealey, Myers, and Allen (2006, chapter 
6)). Controlling for expected cash flows, the NPV decreases with the cost of capital, giving rise to the negative relation between investment and the cost of capital, or expected return. Further, firms' balance-sheet constraint implies that the sources of funds must add up to the uses of funds, suggesting that issuers must invest more than nonissuers. The SEO underperformance then follows from the negative relation between investment and expected returns.

We also examine two related hypotheses. First, the overinvestment hypothesis (e.g., Richardson and Sloan (2003)) suggests that the SEO underperformance is driven by the negative investment-return relation that arises from investors underreacting to overinvestment of empire-building managers (see also Titman, Wei, and Xie (2004)). Second, Eckbo, Masulis, and Norli (2000) show that a six-factor model can explain the SEO underperformance in their sample. Eckbo et al. argue that issuing equity lowers financial leverage for issuers, thus reducing their loadings on risk factors and expected returns relative to nonissuers.

Our evidence is inconsistent with the overinvestment hypothesis. We document that the negative investment-return relation is even stronger among firms with stronger shareholder rights, which should be less vulnerable to overinvestment by empire-building managers, than that among firms with weaker shareholder rights. Moreover, issuers have on average lower governance and entrenchment indexes, suggesting stronger shareholder rights and less vulnerability to overinvestment than matching nonissuers. We measure the strength of shareholder rights using the corporate governance index of Gompers, Ishii, and Metrick (2003) and the entrenchment index of Bebchuk, Cohen, and Ferrell (2005).

Our evidence is also inconsistent with the leverage-based explanation of SEO underperformance on three dimensions. First, the Eckbo-Masulis-Norli (2000) six-factor model fails to reduce the underperformance to insignificant levels in our sample that consists of more 
than 8,000 SEOs. ${ }^{1}$ Second, the cross-sectional relation between leverage and future returns is ambiguous. Using cross-sectional regressions, we show that market leverage correlates with future returns positively, but book leverage correlates with future returns negatively, a pattern also documented in Fama and French (1992). ${ }^{2}$ Third and most importantly, even after equity issuance, issuers have market and book leverage ratios higher than matching nonissuers. From 1970 to 2003, the median market leverage of issuers at the fiscal yearend following the issuance is 0.22 , slightly higher than that of matching nonissuers, 0.19 . The median book leverage of issuers is 0.36 , about $42 \%$ higher than that of nonissuers, 0.21 . Further evidence from 60-month post-event window shows that, although issuing equity lowers issuers' leverage ratios in the first two years, they remain significantly higher than those of nonissuers throughout the post-event window.

Brav, Geczy, and Gompers (2000) document that SEO firms are concentrated among small-growth firms, and suggest that their underperformance reflects a more pervasive return pattern captured by the Fama-French (1993) size and book-to-market factors. Brav and Gompers (1997) make a similar argument in the context of IPOs. Our evidence lends support to their argument because both equity issuers and small-growth firms invest more than other firms. We suggest that capital investment is the common link between these two types of firms, and is likely to be the more fundamental driving force of their underperformance.

Our paper bridges the literatures on the new issues puzzle and on the investment-return relation. Loughran and Ritter (1995) and Spiess and Affleck-Graves (1995) first document that SEO firms underperform nonissuers with similar characteristics during three to five years

\footnotetext{
${ }^{1}$ Eberhart and Siddique (2002) also report that the Eckbo-Masulis-Norli model cannot make the underperformance insignificant in their sample of 189 SEOs issued by 140 industrial firms from 1980 to 1992.

${ }^{2}$ Fama and French (1992) argue that, because the slope on book leverage and the slope on market leverage are opposite in sign but relatively close in magnitudes, it is the difference between market and book leverage, i.e., book-to-market, that helps explain average returns.
} 
after the issuance. Kang, Kim, and Stulz (1999) document similar underperformance following seasoned equity and convertible bond issuance among Japanese firms. Cochrane (1991) documents the negative relation between investment and future average returns in the time series. Titman, Wei, and Xie (2004) find a similar association in the cross section. Li, Vassalou, and Xing (2004) use sectoral investment growth rates to price the cross-section of returns, including the small-growth portfolio. Anderson and Garcia-Feijóo (2005) find that investment growth conditions subsequent classification of firms to size and book-to-market portfolios. Xing (2005) shows that firms with low investment growth or low investment-to-asset ratios have significantly higher expected returns, and that a return factor based on investment contains similar information as HML and explains the value effect empirically as well as HML.

To our knowledge, the only other paper that also connects the aforementioned two literatures is Richardson and Sloan (2003), who show that the external financing-return relation is strongest when the proceeds are invested in non-cash assets. Our work complements theirs because both papers argue that capital investment is likely to be an important driving force of the SEO underperformance. But our paper differs from theirs in several important ways. First, we use factor regressions, while Richardson and Sloan use panel regressions. Second, our investment-related evidence is much more detailed. More importantly, Richardson and Sloan interpret the negative investment-return relation as investors underreacting to overinvestment and aggressive accounting. We argue, on the other hand, that the evidence is consistent with optimal investment based on recent theoretical work of Carlson, Fisher, and Giammarino (2005) and Zhang (2005). We try to distinguish between the two competing hypotheses and find evidence inconsistent with the overinvestment hypothesis.

Our paper is also related to Schultz (2003), who argues that event studies are likely to result in negative ex-post abnormal performance, even though there is no ex-ante un- 
derperformance. ${ }^{3}$ Weighing each period equally as in calendar-time regressions solves this problem. Our investment hypothesis focuses on ex-ante underperformance and thus applies to calendar-time evidence.

Section 2 develops the investment hypothesis of the SEO underperformance. Section 3 describes our data. Section 4 reports our empirical results. Section 5 concludes.

\section{Hypothesis Development}

The investment hypothesis of SEO underperformance argues that the underperformance arises from the negative association between capital investment and expected returns. This hypothesis can be split into two parts. First, the association between capital investment and expected returns should be negative. Second, if investment is financed by issuing new equity, then issuers should have lower expected returns than nonissuers.

Intuitively, a firm's investment increases with the value of positive-NPV projects. The NPVs of new projects are inversely related to their costs of capital or expected returns, ceteris paribus. If the costs of capital are high, then the NPVs are low, giving rise to a low investment-to-asset ratio for the firm. If the costs of capital are low, then the NPVs are high, giving rise to a high investment-to-asset ratio. Figure 1 illustrates the negative relation between investment and expected returns.

The negative investment-return relation is the central prediction in recent theoretical literature on investment-based asset pricing. Two different approaches have been used to develop this relation. The first approach is based on real options theory. In Berk, Green, and

\footnotetext{
${ }^{3}$ If early in a sample period, SEOs underperform, there will be few SEOs in the future because investors would be less interested in them. The average performance will be weighted more towards the early SEOs that underperformed. If early SEOs outperform, there will be more SEOs in the future. The early positive abnormal performance will be weighted less in the average performance. Viswanathan and Wei (2005) show that nonstationarity in the number of event process is necessary to generate a large negative bias emphasized by Schultz (2003).
} 
Naik (1999), firms invest more when they have many low-risk projects. Investment thus lowers risk and expected returns. In Carlson, Fisher, and Giammarino (2004, 2005), expansion options are riskier than assets in place. Investment extinguishes the riskier expansion options, transforming them into less risky assets in place, and reduces risk and expected returns.

The second approach is based on the $Q$-theory. Cochrane $(1991,1996)$ first derives the negative investment-return relation from the $Q$-theory. In his model, firms invest more when their marginal $q$ is high, where the marginal $q$ is the net present value of future cash flows generated from one additional unit of capital. Given expected cash flows, high marginal $q$ is associated with lower costs of capital. The basic mechanisms driving the investment-return relation in the real options and the $Q$-theory models are similar because the two approaches are mathematically equivalent (e.g., Abel, Dixit, Eberly, and Pindyck (1996)).

Figure 1 also shows that equity issuers are associated with the right end of the curve, where expected returns are low, and nonissuers are associated with the left end of the curve, where expected returns are high. Intuitively, the balance-sheet constraint requires that the uses of funds must equal the sources of funds. Equity issuers thus tend to be firms with high investment-to-asset ratios, and vice versa. Based on this observation, Carlson, Fisher, and Giammarino (2005) and Zhang (2005) argue that SEO firms must invest more and should earn lower expected returns than matching nonissuers ex-ante.

Although we test the investment hypothesis in the context of SEOs, the investment-return relation in principle also applies to other external financing anomalies. These anomalies include the underperformance following initial public offerings (e.g., Ritter (1991)), debt offerings (e.g., Spiess and Affleck-Graves (1999)), private placements of equity (e.g., Hertzel, Lemmon, Linck, and Rees (2002)), and loan announcements (e.g., Billett, Flannery, and Garfinkel (2005)), as well as overperformance following dividend initiations (e.g., Michaely, Thaler, and 
Womack (1995)), tender offers (e.g., Lakonishok and Vermaelen (1990)), and open market share repurchase (e.g., Ikenberry, Lakonishok, and Vermaelen (1995)). Zhang (2005) argues that these anomalies are all potentially driven by optimal investment. Intuitively, from the balance-sheet constraint, firms raising capital should invest more and earn lower expected returns, and firms distributing capital should invest less and earn higher expected returns.

\section{Data}

We obtain our sample of SEO firms from Thomson Financial's SDC database and monthly returns from the Center for Research in Security Prices (CRSP). The sample period is from 1970 to 2003. The monthly returns of the Fama and French (1993) factors, the returns of the momentum factor, and the risk-free rate are from Kenneth French's website. We obtain accounting information from the Compustat Annual Industrial Files.

Our sample selection criteria largely follow previous studies. To be included, a SEO must be performed by a U.S. firm, which must have returns on CRSP at some point during the five-year period after its offering. We exclude unit offerings and secondary offerings in which new shares are not issued. We also exclude SEOs of firms that trade on exchanges other than NYSE, AMEX, and NASDAQ. Similar to Brav, Geczy, and Gompers (2000) and Eckbo, Masulis, and Norli (2000), but different from Loughran and Ritter (1995), we include SEOs of utilities in our sample. Exclusion of utilities from the sample does not change our results materially because the proportion of utilities is relatively small, about $13 \%$. Following Loughran and Ritter, we define utilities as firms with SIC codes ranging between 4,910 and 4,949 . The results are also robust to the exclusion of mixed offerings from the sample. ${ }^{4}$

Table 1 reports the number of SEOs for each year in the sample, the number of SEOs

\footnotetext{
${ }^{4} \mathrm{~A}$ mixed offering is a combination of a primary offering, in which new shares are issued, and a secondary offering, in which shares change ownership but no new equity is issued.
} 
matched with CRSP using CUSIPs and historical CUSIPs, the numbers of equity issues for NYSE/AMEX/NASDAQ firms, the number of primary and mixed offerings, and the number of offerings by non-utilities and non-financial firms. From the last row of Table 1, our sample includes 11,092 SEOs with 8,126 SEOs having stock price data. Because of the long sample period of 34 years, our sample seems to be the largest in the literature. For comparison, Eckbo, Masulis, and Norli's (2000) sample includes 4,766 SEOs, Loughran and Ritter's (1995) contains 3,702 SEOs, and Brav, Geczy, and Gompers's (2000) includes 4,622 SEOs.

The second column of Table 1 contains the number of SEOs for each year in the sample, and the fourth column shows the number of SEOs obtained by matching SDC and CRSP firms based on their CUSIP numbers. Comparing these two columns reveals that matching by both current and historical CUSIPs increases the number of SEOs by more than $28 \%$. This increase is especially pronounced during the earlier years in the sample, in which it often exceeds 60\%. The sample of SEOs is heavily tilted towards NYSE firms in the 1970's, but NASDAQ firms dominate the latter part of the sample.

Panel A of Figure 2 presents the frequency distribution of equity issuers across quintiles of size and book-to-market. To generate this result, we merge CRSP returns (matched with SDC data) from July of year $t$ to June of year $t+1$ with Compustat accounting data at fiscal yearend in calendar year $t-1$. We measure the market size as the share price at the end of June times shares outstanding. Book equity is the stockholder's equity (item 216), minus preferred stock, plus balance sheet deferred taxes and investment tax credit (item 35) if available, minus post-retirement benefit asset (item 330) if available. If stockholder's equity is missing, we use common equity (item 60) plus preferred stock par value (item 130). If these variables are missing, we use book assets (item 6) less liabilities (item 181). Preferred stock is defined as preferred stock liquidating value (item 10), or preferred stock redemption 
value (item 56), or preferred stock par value (item 130) in that order of availability. To compute the book-to-market ratio, we use December closing price times number of shares outstanding. The quintile breakpoints are from Kenneth French's website.

Consistent with Brav, Geczy, and Gompers (2000), we find that issuers tend to be smallgrowth firms. Firms in the smallest size quintile and the lowest book-to-market quintile issue seasoned equity about six times more frequently than firms in the largest size and the highest book-to-market quintiles. Panel B of Figure 2 reports the median new equity-to-asset ratio among issuers by size and book-to-market quintiles. We measure this ratio as the market value of new equity from SDC divided by the book assets at the fiscal yearend preceding a SEO. The distribution of the median new equity-to-asset across size and book-to-market quintiles is similar to the frequency distribution reported in Panel A. Small-growth firms issue equity not only more frequently, they also issue much more as a percentage of their asset value. For example, the median new equity-to-asset of issuers that belong to the small-growth portfolio is about 55 times higher than that of issuers that belong to the big-value portfolio.

\section{Empirical Results}

Section 4.1 documents SEO underperformance in our sample. Section 4.2 constructs a common factor of returns based on capital investment. Section 4.3 presents our central finding that investment drives the SEO underperformance. To understand the underlying intuition, Section 4.4 examines the investment behavior of issuers relative to that of nonissuers. Section 4.5 tests two alternative explanations of SEO underperformance. 


\subsection{Documenting SEO Underperformance}

We measure SEO underperformance as Jensen's alphas from factor regressions. We use factor regressions because recent literature has discussed in depth the difficulties in obtaining unbiased inferences using cumulative abnormal returns and buy-and-hold returns. ${ }^{5}$ The factor models we use include the CAPM, the Fama and French (1993) three-factor model, as in Ritter (2003). The dependent variable in the factor regressions is the portfolio return of SEO firms in excess of the one-month Treasury bill rate. The SEO portfolio consists of all the firms that have issued seasoned equity in the past 36 months. For robustness, we also use an alternative period of 60 months.

Panel A of Table 2 reports factor regressions using portfolios of firms with prior 36month SEOs. It shows that the alpha from the CAPM regression of the equally-weighted SEO portfolio is $-0.28 \%$ per month with a marginally significant $t$-statistic of -1.91 . The alpha of the value-weighted SEO portfolio in the CAPM regression is $-0.36 \%$ per month with a significant $t$-statistic of -3.56 . The results from the Fama-French model are similar. The alpha of the equally-weighted SEO portfolio in the Fama-French model is $-0.29 \%$ per month with a significant $t$-statistic of -2.89 , and the alpha of the value-weighted portfolio is $-0.28 \%$ with a significant $t$-statistic of -2.92 . Brav, Geczy, and Gompers (2000) do not report the CAPM regressions, but our alphas from the Fama-French model are similar to theirs.

The literature has also defined the SEO portfolios as consisting of firms that have issued seasoned equity in the prior 60 months. Panel B of Table 2 reports the factor regressions using this definition of SEO portfolios. Comparing Panels A and B shows that the magnitudes of the SEO underperformance are somewhat lower using prior 60-month SEOs. But

\footnotetext{
${ }^{5}$ Barber and Lyon (1997), Kothari and Warner (1997), Fama (1998), Mitchell and Stafford (2000), among others, discuss the difficulty of computing unbiased significance levels using buy-and-hold returns. Schultz (2003) and Butler, Grullon, and Weston (2005) discuss the difficulty with cumulative abnormal returns.
} 
the alphas of the equally-weighted and value-weighted SEO portfolios from the Fama-French model and the alpha of the value-weighted SEO portfolio from the CAPM regression are all significant. And their magnitudes, ranging from $-0.21 \%$ to $-0.25 \%$ per month or $-2.5 \%$ to $-3 \%$ per annum, are economically meaningful.

Perhaps surprisingly, Table 2 shows that the equally-weighted underperformance is lower in magnitude than the value-weighted underperformance using the CAPM. And their magnitudes are similar using the Fama-French three-factor model. This pattern differs from that found in previous studies, as summarized by Ritter (2003, Table 3), i.e., equally-weighted underperformance is larger in magnitude than value-weighted underperformance.

This difference can be reconciled by two observations. First, all the studies cited in Ritter only measure the underperformance with the Fama-French model. Second, when we restrict our sample period to that comparable to previous studies, we largely replicate previous findings. Specifically, using our sample of SEOs from 1975 to 1996 and prior 60-month SEO portfolios, we find that the equally-weighted alpha from the Fama-French model to be $-0.32 \%$ per month $(t$-statistic $=-4.26)$. And the value-weighted alpha is almost halved, $-0.15 \%$ $(t$-statistic $=-1.80)$. For comparison, using the same sample period and definition of SEO portfolios, Brav, Geczy, and Gompers (2000) report an equally-weighted alpha of -0.37\% per month $(t$-statistic $=-4.81)$ and a value-weighted alpha of $-0.14 \%(t$-statistic $=-1.36)$.

Eckbo, Masulis, and Norli (2000, EMN) show that the SEO underperformance from their six-factor model is insignificant. These factors include (i) RM, the excess return on the CRSP value-weighted market index; (ii) $\triangle \mathrm{RPC}$, a factor mimicking portfolio for the percent change in the real per capita consumption of nondurable goods; (iii) BAA-AAA, a factor mimicking portfolio for the difference in the monthly yield changes on bonds rated BAA and AAA by Moody's; (iv) UI, a factor mimicking portfolio for unanticipated inflation generated from 
a model of expected inflation involving a regression of return on 30-day Treasury bills less inflation onto 12 of its lagged values and a constant; (v) 20y-1y, the return difference between Treasury bonds with 20 years to maturity and Treasury bonds with one year to maturity; and (vi) TBILLspr, the return difference between 90-day and 30-day Treasury bills.

Table 3 replicates their analysis using our sample. The sample period is from January 1970 to December 2002 because the data of the EMN factors from Øyvind Norli end at December 2002. The table shows that the EMN result is largely specific to their sample. In our sample with more than 8,000 SEOs, the EMN model performs worse than the CAPM and the Fama-French (1993) three-factor model in explaining the SEO underperformance. Specifically, when we regress equally-weighted excess returns of prior 36-month SEO portfolio onto the EMN factors, we obtain an alpha of $-0.52 \%$ with a significant $t$-statistic of -3.22 . And its value-weighted counterpart is $-0.36 \%(t$-statistic $=-3.38)$. The evidence suggests that there is room to explore other factors underlying the SEO underperformance. ${ }^{6}$

\subsection{Constructing the Investment Factor}

As a direct test of the investment hypothesis outlined in Section 2, we augment traditional factor models with a common factor based on capital investment. This factor is the zero-cost portfolio from buying stocks with the lowest $30 \%$ investment-to-asset ratios and selling stocks with the highest 30\% investment-to-asset ratios, controlling for size and book-to-market.

Specifically, we construct the investment factor from a $3 \times 3 \times 3$ sort on size, book-tomarket, and investment-to-asset ratio. We measure investment-to-asset as the annual change in gross property, plant and equipment (Compustat item 7) divided by the lagged book value

\footnotetext{
${ }^{6}$ In untabulated results, we find that the underperformance of SEO firms is insignificant in the Carhart (1997) four-factor regressions, a finding also documented in Brav, Geczy, and Gompers (2000). Similar to Brav et al., we do not interpret this evidence as suggesting no SEO underperformance. The reason is that both the economic forces driving momentum profits and their connections to long-term performance following equity issuance are unclear. In short, we are reluctant to use one anomaly to explain another.
} 
of assets (item 6). In June of each year, we sort stocks in ascending order independently on size, book-to-market, and investment-to-asset into three groups, the top 30\%, the medium $40 \%$, and the bottom 30\%. By taking intersections of these nine portfolios, we classify all firms into 27 portfolios. The investment factor, denoted INV, is defined as the average returns of the low-investment portfolios minus the average returns of the high-investment portfolios. Formally, let $p_{i j k}$, where $i, j, k=1,2,3$, denote the value-weighted portfolio returns of firms in the $i^{\text {th }}$ group of size, the $j^{\text {th }}$ group of book-to-market, and the $k^{\text {th }}$ group of investment-toasset. And we define the investment factor as $(1 / 9) \sum_{i=1}^{3} \sum_{j=1}^{3} p_{i j 1}-(1 / 9) \sum_{i=1}^{3} \sum_{j=1}^{3} p_{i j 3}$.

In the sample from January 1970 to December 2003, the average return of the investment factor is $0.37 \%$ per month, or $4.4 \%$ per annum, with a heteroscedasticity-consistent $t$-statistic of 4.35. This average return of the investment factor is both economically and statistically significant. For comparison, in the same sample period, the average market excess return is $0.47 \%$ per month, or $5.69 \%$ per annum $(t$-statistic $=2.00)$, and the average return of HML is $0.49 \%$ per month, or $5.83 \%$ per annum $(t$-statistic $=2.65)$.

More importantly, standard factor models cannot capture much of the average return or variation of the investment factor. Table 4 regresses the investment factor onto the market excess return, the Fama-French (1993) three factors, and the EMN six factors. From the first row of Table 4, the investment factor has significantly positive alphas of $0.40 \%, 0.27 \%$, and $0.28 \%$ per month in the CAPM, Fama-French, and the EMN models, respectively. All the alphas are highly significant. Moreover, the goodness-of-fit coefficients are generally low, ranging from $1.09 \%$ in the CAPM to $12.44 \%$ in the Fama-French model. Using the EMN six-factor model yields a goodness-of-fit coefficient of only $8.87 \% .^{7}$ The evidence suggests that the investment factor captures sources of cross-sectional variation of stock returns that

\footnotetext{
${ }^{7}$ Regressing the investment factor onto the Carhart (1997) four factors yields an alpha of 0.18\% ( $t$-statistic $=2.21$ ) and a goodness-of-fit coefficient of $16.87 \%$.
} 
are largely independent of those captured by standard factor models.

Table 4 also shows that the slope of the investment factor on HML, 0.20 , is the highest among all the slopes, and is highly significant. In untabulated results, we find that the unconditional correlation of the investment factor with HML is 0.33 , much higher than those with other factors $(-0.12$ with MKT and -0.05 with SMB). This evidence suggests an important link between the investment factor and the value factor, consistent with the evidence in Anderson and Garcia-Feijóo (2005) and Xing (2005).

Following Fama and French (1993), we interpret the investment factor as a common factor in the cross-section of returns. While Fama and French interpret their size and value factors as risk factors motivated from ICAPM or APT, we do not take a stance on risk interpretation of our investment factor. Two arguments support the risk interpretation. First, none of the theoretical papers (e.g., Cochrane (1991) and Berk, Green, and Naik (1999), see Section 2) that we use to motivate the construction of the investment factor assumes any form of behavioral bias. Second, unlike size and book-to-market, investment-to-asset does not directly involve market valuation, and is thus less likely to be affected by mispricing.

However, behavioral stochastic discount factors (e.g., Barberis, Huang, and Santos (2001)) are also consistent with the predictions of the partial equilibrium models discussed in Section 2. Investor sentiment can in principle affect investment policy through shareholder discount rates (e.g., Polk and Sapienza (2005)). Moreover, it is possible that characteristics-based and covariance-based explanations of the expected-return variations are not mutually exclusive. Under certain conditions, there exists a one-to-one mapping between covariances and characteristics, suggesting that they can both serve as sufficient statistics for expected returns (e.g., Zhang (2005)). Consequently, our empirical goal is to search for a parsimonious factor specification motivated by economic theory, behavioral or rational, a specification that can 
be used to quantitatively explain asset pricing anomalies.

\subsection{Testing the Investment Hypothesis}

Table 5 reports our central finding. Adding the investment factor into standard factor regressions makes SEO underperformance largely insignificant and reduces its magnitude by around 40\%. From Panel A, the equally-weighted alpha of prior 36-month SEOs from the CAPM decreases by $46 \%$ in magnitude from $-0.28 \%$ to $-0.15 \%$ per month. Its $t$-statistic drops from -1.91 to -0.94 . The equally-weighted alpha from the Fama-French (1993) model decreases in magnitude from $-0.29 \%$ to $-0.17 \%$ per month, a reduction of $43 \%$ with the $t$-statistic dropping from -2.89 to -1.62 . We obtain similar results using the value-weighted, prior 36-month SEOs. The alpha from the CAPM decreases from $-0.36 \%$ without the investment factor to $-0.20 \%$ per month with the investment factor, a reduction of $45 \%$ in magnitude, with the $t$-statistic dropping from -3.56 to -2.12 , albeit still being significant. The value-weighted alpha from the Fama-French model drops from $-0.28 \%$ to $-0.18 \%$, a reduction of $37 \%$ in magnitude. The $t$-statistic drops from -2.92 to -1.91 .

Panel A of Table 5 also shows that the loadings of the SEO portfolios on the investment factor are negative and significant in all specifications. The magnitudes of these loadings, ranging from -0.32 to -0.47 , are economically meaningful. Given the average return of $0.37 \%$ per month for the investment factor, these loadings can explain from $0.12 \%$ to $0.17 \%$ per month, or $1.4 \%$ to $2 \%$ per annum of the SEO underperformance.

Panel B of Table 5 reports similar results using prior 60-month SEO portfolios. Once we augment the factor models with the investment factor, the magnitudes of the SEO underperformance decrease by $36 \%$ to $45 \%$ in the CAPM and the Fama-French factor regressions. All the alphas become insignificant. Moreover, the loadings of SEO portfolios on the investment 
factor are universally negative and, except for one case, highly significant. The magnitudes of the loadings range from -0.12 to -0.32 , and can explain from $0.05 \%$ to $0.12 \%$ per month or $0.6 \%$ to $1.4 \%$ per annum of the SEO underperformance.

\section{Issuer-Purged Factor Regressions}

Loughran and Ritter (2000) argue that the Fama-French (1993) model as implemented traditionally has low statistical power for detecting SEO underperformance. The reason is that these factor returns are constructed using in part the returns of the issuers being tested for underperformance. Loughran and Ritter purge the size and value factors from issuing firms' returns because the two factors are empirically motivated, and are not necessarily priced risk factors in equilibrium. The market factor does not need to be purged because there are many theoretical reasons to believe that it is a priced risk factor.

To quantify the effects of purging, we perform issuer-purged Fama-French factor regressions with and without the investment factor. The data of the purged size and value factors are from Jay Ritter's website. Loughran and Ritter (2000) construct these factors after deleting all firms that have publicly issued equity during the prior five years. We use the same purging procedure to construct our purged investment factor. Because we purge out prior 60-month SEOs, the sample used in purged factor regressions starts at January 1975.

Purging issuers does not affect the basic properties of the investment factor. The average return of the purged investment factor, denoted pINV, is $0.35 \%$ per month or $4.2 \%$ per annum with a $t$-statistic of 3.76 . The alpha of the purged investment factor from the CAPM regression is $0.38 \%$ per month $(t$-statistic $=4.00)$. And its alpha from purged Fama-French factor regression is $0.29 \%$ per month $(t$-statistic $=3.04)$. Finally, the correlation between the unpurged and purged investment factors is 0.90 . 
Table 6 reports the issuer-purged factor regressions. Although weakened somewhat quantitatively, our basic result on the importance of investment in driving SEO underperformance remains unchanged. From Panel A, adding purged investment factor into purged FamaFrench three-factor regression reduces the magnitude of underperformance for the equallyweighted prior 36 -month SEO portfolio by about $36 \%$ from $-0.39 \%$ to $-0.25 \%$ per month. The corresponding $t$-statistic drops from -3.28 to -2.11 , albeit still being significant. The value-weighted alpha drops by $23 \%$ in magnitude from $-0.33 \%$ to $-0.26 \%$ (the $t$-statistic drops from -2.85 to -2.26$)$. Panel $\mathrm{B}$ reports similar results using prior 60 -month SEO portfolios. The equally-weighted alpha drops by $37 \%$ from $-0.28 \%$ to $-0.17 \%$, and the value-weighted alpha drops by $23 \%$ from $-0.23 \%$ to $-0.18 \%$. In both cases, adding purged investment factor reduces significant SEO underperformance to insignificant levels.

Table 6 also reports factor regressions with purged size and value factors but unpurged investment factor. We also consider unpurged investment factor because investment emerges as a priced factor across diverse equilibrium models in recent investment-based asset pricing literature spurred by Cochrane $(1991,1996)$ and Berk, Green, and Naik (1999). Table 6 shows that using unpurged investment factor further reduces the magnitude of underperformance. The percentage reduction in the magnitude of alpha from adding the investment factor into purged Fama-French (1993) model ranges from $43 \%$ for the value-weighted prior 36-month SEO portfolio to $50 \%$ for the equally-weighted, prior 60 -month SEO portfolio. All the alphas are insignificant in the augmented factor regressions.

\section{Event-Time Factor Regressions}

To study how the SEO underperformance evolves over the post-SEO years, we perform eventtime factor regressions (e.g., Ball and Kothari (1989)). The difference between event-time 
regressions and calendar-time regressions is that we now have three separate SEO portfolios on the left-hand side of regressions. The first portfolio consists of firms that have issued equity in the prior 12 months, the second portfolio consists of firms that have issued equity between 13 and 24 months ago, and the third portfolio consists of firms that have issued equity between 25 and 36 months ago. ${ }^{8}$

Tables 7 and 8 report event-time factor regressions with and without the investment factor using equally-weighted and value-weighted SEO portfolios, respectively. The underperformance appears mostly in the first two years, especially in the second year. Specifically, from Panel A of Table 7, the equally-weighted alpha in the CAPM regression in the first post-event year is only $-0.15 \%$ per month $(t$-statistic $=-0.96)$. The alpha increases to $-0.63 \%(t$-statistic $=-3.77)$ in year two, and then drops to $-0.02 \%(t$-statistic $=-0.12)$ in year three. Using the Fama-French (1993) model yields similar results. Panel A of Table 8 reports similar results using value-weighted SEO portfolios. The difference is that the value-weighted alphas in year one from the CAPM and the Fama-French model are $-0.30 \%$ and $-0.24 \%$ with significant $t$-statistics of -2.52 and -2.07 respectively.

More importantly, depending on factor model and post-event horizon, adding the investment factor explains $28-75 \%$ of the equally-weighted underperformance and $23-50 \%$ of the value-weighted underperformance. Specifically, from Panel B of Table 8, the value-weighted alphas from the CAPM and the Fama-French model reduce from significant $-0.30 \%$ and $-0.24 \%$ in year one to $-0.15 \%(t$-statistic $=-1.34)$ and $-0.14 \%(t$-statistic $=-1.22)$, respectively. Although the investment factor explains a fair amount of underperformance, both the equally-weighted and the value-weighted alphas from the CAPM and the Fama-French

\footnotetext{
${ }^{8}$ We have also used SEO portfolios that consist of firms with seasoned equity between 37 and 48 months and between 49 and 60 months ago. But the underperformance mostly concentrates in the first three postSEO years. To save space, we thus only present event-time regressions for the first three post-SEO years.
} 
models remain economically and statistically significant in the second post-event year.

The event-time regressions also reveal some interesting patterns on time-varying factor loadings. The loadings on the investment factor are all negative, and are highly significant in most specifications. The magnitudes of these loadings display a hump shape across the three post-event years, where the loadings in year two are the highest. This loading pattern is similar to the pattern in the magnitude of the underperformance across the post-event years.

\subsection{Why Does Investment Help Explain SEO Underperformance?}

We now ask why the investment factor helps explain the SEO underperformance. To this end, we examine the investment behavior of seasoned equity issuers relative to nonissuers with similar size and book-to-market. Our basic result is that issuers invest much more than matching nonissuers at the time of issuance. The dispersion in investment-to-asset between these two classes of firms does not converge until five years after portfolio formation. Because low-investment firms earn higher average returns than high-investment firms, it is natural that the investment factor helps explain the underperformance.

Each month we independently sort all firms that have not issued equity within prior 60 months into quintiles of size and book-to-market using the breakpoints from Kenneth French's website. As a result, we have 25 size and book-to-market portfolios of nonissuers. For each issuer, we use these breakpoints to identify its matching portfolio. We then compare the median characteristics of the matching portfolio with those of the issuer. We choose to match issuers with nonissuers by size and book-to-market because these two characteristics are primary determinants of the cross-section of returns (e.g., Fama and French (1992)). Matching firms to individual nonissuers as in Loughran and Ritter (1997), instead of size and book-to-market portfolios, produces quantitatively similar results. 
Figure 3 reports SEO firms' and matching firms' median investment-to-asset and profitability in the 60 months after equity issuance. To measure statistical significance of the differences in characteristics, we also report $Z$-statistics associated with Wilcoxon matchedpairs signed-rank tests, following Loughran and Ritter (1997). The null hypothesis is that the distributions of issuers' and nonissuers' characteristics are identical. $Z$-statistics between -2 and 2 indicate failure to reject the null hypothesis. ${ }^{9}$

Panel A of Figure 3 documents a large dispersion in investment-to-asset between issuers and matching nonissuers for most of the post-event window. In the first year after issuance, issuers' investment-to-asset ratio is around 0.09, about $40 \%$ higher than nonissuers' investment-to-asset ratio, around 0.055. This dispersion remains stable for almost two years after issuance and then starts to decline. The investment-to-asset ratio of issuers converges fully to that of non-issuers at the end of the 60-month post-event window. From Panel B, the dispersion in investment-to-asset ratio is highly significant, especially in the few years after issuance. Finally, Panels C and D show that issuers are more profitable than matching nonissuers in the first three years after equity issuance, but become less profitable than nonissuers thereafter. But the dispersion in profitability between issuers and matching nonissuers is both economically and statistically less significant than the dispersion in investment-to-asset.

Extending the event-time evidence in Figure 3, Table 9 reports calendar-time evidence on issuers' and matching nonissuers' investment-to-asset and profitability in the year preceding their SEOs. From Panel A, issuers invest more than nonissuers, and the difference in

\footnotetext{
${ }^{9}$ Denote the difference in the characteristic between issuer $i$ and its matching portfolio by $d_{i}$. We rank the absolute values of $d_{i}$ 's from 1 to $n$, where $n$ is the number of SEOs. We next sum the ranks of the positive values of $d_{i}$ and denote the sum by $D$. The $Z$-statistic is then $Z \equiv\left[D-\frac{n(n+1)}{4}\right] / \sqrt{\frac{n(n+1)(2 n+1)}{24}}$. Under the null, $Z$ follows a standard normal distribution. Importantly, in rare cases the sign of the Zstatistic can be inconsistent with the sign of the difference between issuing firms' and matching portfolios' median characteristics. The reason is that the Wilcoxon test is concerned with the whole distribution of characteristics, and not just with the medians.
} 
investment-to-asset ratio is significant for every year from 1970 to 2003 . The sample average investment-to-asset ratio of issuers is 0.09 , about $40 \%$ higher than that of nonissuers, 0.054 . The $Z$-statistic is highly significant, suggesting that issuers have a different distribution of investment-to-asset than nonissuers. Panel B shows that issuers have somewhat higher profitability than nonissuers. But the magnitude of this dispersion is very small, only 0.001 .

Although broadly consistent with the evidence in Loughran and Ritter (1997), our results shed additional light on the driving forces of the SEO underperformance. Loughran and Ritter document that issuers have higher ratios of capital expenditure plus R\&D expense relative to assets than nonissuers for four years after issuance. Specifically, their Figure 1 reports that this ratio is about $10.5 \%$ for issuers and $6 \%$ for nonissuers at the time of issuance. A comparison with Panel A of our Figure 3 reveals that this dispersion is mostly due to capital investment, not $R \& D$ expense.

This evidence is important. First, our empirical analysis is motivated from the theoretical work of Carlson, Fisher, and Giammarino (2005) and Zhang (2005), who model directly the relation between returns and capital investment, not R\&D. Second and more importantly, unlike the negative association between investment-to-asset and future returns, the empirical association between R\&D-to-asset and future returns is positive (e.g., Chan, Lakonishok and Sougiannis (2001) and Chambers, Jennings and Thompson (2002)). Chu (2005) argues that this difference arises because growth options tend to be riskier than assets in place, and R\&D generates growth options, while capital investment extinguishes growth options.

Supplementing Table 9, Figure 4 presents the number of SEO firms across investmentto-asset deciles. We sort nonissuing firms in June of each year on their investment-to-asset ratios to obtain the decile breakpoints. We then assign each issuer to one of the deciles based on the breakpoints. Figure 4 shows that issuers are likely to be firms with high investment- 
to-asset ratios. Firms in the highest investment-to-asset decile issue seasoned equity about three and a half times more frequently than firms in the lowest investment-to-asset decile.

In sum, we present strong evidence that SEO firms invest much more than matching nonissuers both before and after issuance. This evidence, combined with the fact that the low-minus-high investment-to-asset factor earns a significant $0.37 \%$ per month, explains why this factor can substantially reduce the magnitude of SEO underperformance.

\subsection{Exploring Alternative Hypotheses}

This subsection explores two alternative explanations of the SEO underperformance.

\section{Testing the Overinvestment Hypothesis}

Similar to our hypothesis, the overinvestment hypothesis of Richardson and Sloan (2003) argues that the underperformance results from the negative relation between investment and average returns. The big difference is that while we argue that optimal investment drives the negative relation between investment and expected returns, Richardson and Sloan argue that investor underreaction to overinvestment by empire-building managers drives the negative relation between investment and average abnormal returns, as in Titman, Wei, and Xie (2004).

We aim to distinguish the overinvestment hypothesis from our optimal-investment hypothesis. Investor underreaction and overinvestment are two necessary conditions for the overinvestment hypothesis to work. Testing underreaction directly would require a model of the normal level of reaction. Because the literature has not converged on such a model, we focus instead on the other necessary condition, i.e., overinvestment.

The idea is simple. Under the overinvestment hypothesis, the negative investment-return relation should be stronger among firms more vulnerable to overinvestment by empire- 
building managers. To implement this idea, we split the sample into two based on exante measures of vulnerability to empire-building. We then perform Fama-MacBeth (1973) cross-sectional regressions of future returns onto investment-to-asset ratio and compare the magnitudes of the slopes across the two subsamples. As a more direct test, we also compare measures of vulnerability to empire-building across issuers and matching nonissuers.

We measure a firm's vulnerability to empire-building using the corporate governance index of Gompers, Ishii, and Metrick (2003). Democratic firms with strong shareholder rights (low values of the governance index) should be less vulnerable to overinvestment than dictatorial firms with weak shareholder rights (high values of the governance index). Indeed, Gompers et al. show that firms with stronger shareholder rights have lower capital expenditures and make fewer corporate acquisitions than firms with weaker shareholder rights. Under the overinvestment hypothesis, firms with strong shareholder rights should display weaker investment-return relation than firms with weak shareholder rights.

We take the intersection of our sample and the sample (from 1990 to 2003) of Gompers, Ishii, and Metrick (2003) from Andrew Metrick's website. This intersection gives us a sample that has between 1315 and 1990 firms each year with an average of 1585 firms. We define the democratic sample with the governance index less than or equal to nine (the median) and the dictatorial sample with the governance index greater than or equal to ten.

The evidence in Table 10 is inconsistent with the overinvestment hypothesis. Panels A and B show that the slope on investment-to-asset ratio in univariate regressions is on average -1.31 in the democratic sample. The slope is -0.79 , about $40 \%$ lower in magnitude, in the dictatorial sample. Adding size and book-to-market to the regression yields quantitatively similar results. The slope on investment-to-asset becomes -0.94 in the democratic sample, and its magnitude is more than $50 \%$ higher than that in the dictatorial sample, -0.44 , which 
is insignificant. This evidence suggests that overinvestment is unlikely to be the driving force of the negative investment-return relation. ${ }^{10}$

Our basic result is robust to using an alternative measure of vulnerability to empirebuilding. Several papers have recently questioned the governance index constructed in Gompers, Ishii, and Metrick (2003). Bebchuk, Cohen, and Ferrell (2005) show that an entrenchment index based on six out of 24 IRRC provisions fully drives the negative relation between the governance index and stock returns (see also Bebchuk and Cohen (2004)). The relation between the entrenchment index and future stock returns is robust during the 1990-2003 period. In contrast, Core, Guay, and Rusticus (2005) show that the correlation between the governance index and future returns exhibit a reversal from 2000 to 2003 following Gompers, Ishii, and Metrick's sample period from 1990 to 1999.

Further, the entrenchment index can be a more precise measure of vulnerability to empirebuilding than the governance index. Among the six provisions included in the entrenchment index are four provisions that limit the power of a majority of shareholders (staggered boards, limits to shareholder bylaw amendments, supermajority requirements for mergers, and supermajority requirements for charter amendments) and two provisions that reduce the likelihood of a hostile takeover (poison pills and golden parachutes).

We repeat all the tests after replacing the governance index with the entrenchment index. The sample is the interaction of our sample and the sample (from 1991 to 2003) of Bebchuk, Cohen, and Ferrell (2005) from Lucian Bebchuk's website. We define the low-entrenchment sample with the entrenchment index less than or equal to two (the median) and the highentrenchment sample with the index greater than or equal to three. From Panels $\mathrm{C}$ and

\footnotetext{
${ }^{10}$ The weakly negative slopes on book-to-market in Table 10 are not surprising. The sample period in Gompers, Ishii, and Metrick (2003) is largely the expansionary period from 1990 to 2003, in which growth firms outperformed value firms most of the time (e.g., Petkova and Zhang (2005)). And the sample mostly contains large firms, among which the value premium is weak.
} 
D in Table 10, our basic result remains unchanged. The average slope on investment-toasset in univariate regressions is -0.91 in the low-entrenchment sample, but is -0.73 in the high-entrenchment sample. If we control for size and book-to-market, the average slope on investment-to-asset becomes -0.60 in the low-entrenchment sample, and the average slope in the high-entrenchment sample is only -0.20 .

Going further than analyzing the driving force of the investment-return relation, we now examine the overinvestment hypothesis in the context of SEOs. If the overinvestment hypothesis is true, issuers should have weaker shareholder rights (high governance index) and higher degrees of entrenchment (high entrenchment index), and should be more vulnerable to empire-building than matching nonissuers.

The evidence is again inconsistent with the overinvestment hypothesis. Panels A and B in Table 11 report that, from 1990 to 2003, issuers have on average lower governance indexes, suggesting stronger shareholder rights, than matching nonissuers, with the difference in means being significant. Although the median governance index is the same across issuers and nonissuers, the Wilcoxon test shows that the index distribution of issuers is more leftskewed. Finally, Panels $\mathrm{C}$ and D report similar results using the entrenchment index.

Supplementing the calendar-time evidence in Table 11, the event-time evidence in Figures 5 and 6 shows basically the same picture. The median governance indexes of issuers and nonissuers both equal nine during the first two post-SEO years. Afterwards the median index of issuers drops to eight, while the index of nonissuers remains constant at nine. The median entrenchment indexes of issuers and nonissuers remain at two throughout the five-year post-event window. But the Wilcoxon tests report consistently more left-skewed governance-index and entrenchment-index distributions for issuers during the five post-SEO years. Issuers have lower mean governance and entrenchment indexes than matching nonis- 
suers, and the differences in means are mostly significant.

\section{Testing the Leverage Hypothesis}

Eckbo, Masulis, and Norli (2000) document that equity issuers have lower exposures to risk factors such as unexpected inflation, default spread, and changes in the slope of the term structure. Their multifactor model based on these variables can reduce the SEO underperformance to insignificant levels. Eckbo et al. argue that issuing equity lowers issuers' leverage and reduces their risk and expected returns relative to those of matching nonissuers.

A necessary condition for this explanation is that after SEOs, issuers should have lower leverage than matching nonissuers. If issuers have higher leverage, their lower loadings on risk factors than those of nonissuers must be driven by forces unrelated to leverage. As a direct test, we compare market leverage and book leverage across issuers and matching nonissuers. We find that, contrary to the leverage hypothesis, issuers have higher leverage than matching nonissuers even after equity issuance.

We measure book leverage as the sum of debt in current liabilities (item 9) and long-term debt (item 34) divided by the lagged book value of assets. The denominator of the market leverage ratio is the market value of the firm, which is the sum of the market value of equity (December closing price times number of shares outstanding) and the book value of debt (item 9 plus item 34). Our results are robust to changes in the definition of leverage, such as classifying preferred equity as debt.

Table 12 reports that, from 1970 to 2003, both market and book leverage ratios of issuers, measured at the fiscal yearend following issuance, are usually higher than those of nonissuers. The median market leverage of issuers is 0.22 , slightly higher than the median market leverage of nonissuers, 0.19. And the $Z$-statistic from the Wilcoxon equal-distribution test is 16.96 . 
Except for the year 2000, issuers have higher market leverage than nonissuers in all the other years in the sample, and the difference is mostly significant. The dispersion in book leverage is even larger. The book leverage of issuers is on average 0.36 , while that of nonissuers is only $0.21(Z$-statistic $=38.89)$. Issuers have higher book leverage than nonissuers during every year in the sample, and the $Z$-statistics are all significant.

Figure 7 reports the event-time evolution of leverage for issuers and matching nonissuers for 60 months after issuance. From Panels A and C, although issuing equity lowers somewhat the leverage ratios of issuers during the first two post-event years, their leverage ratios are still higher than those of matching nonissuers. The $Z$-statistics reported in Panels B and D suggest that the differences in leverage ratios are significant throughout the post-event window.

In untabulated tests, we also conduct Fama-MacBeth (1973) cross-sectional regressions of future returns onto market and book leverage. In univariate regressions, book leverage has a monthly average slope of $-0.31 \%(t$-statistic $=-4.19)$. And the market leverage has a average monthly slope of $0.38 \%(t$-statistic $=1.45)$. When market and book leverage are used jointly, their slopes are $0.91 \%(t$-statistic $=3.00)$ and $-0.78 \%(t$-statistic $=-6.11)$, respectively. The pattern that the two leverage ratios are correlated to future returns but with opposite signs is consistent with Fama and French (1992). But more importantly, the negative relation between book leverage ratios and future returns is again inconsistent with the leverage explanation of SEO underperformance.

Finally, the leverage hypothesis is inconsistent with underperformance following debt offerings documented by Spiess and Affleck-Graves (1999). According to the leverage hypothesis, issuing debt increases leverage and equity risk, debt issuers should thus outperform matching nonissuers. But the evidence can be consistent with our investment hypothesis. ${ }^{11}$

\footnotetext{
${ }^{11}$ Eckbo, Masulis, and Norli (2000) also propose the liquidity hypothesis, i.e., issuing equity increases stock
} 


\section{Conclusion}

We study investment-related sources of long-run underperformance following seasoned equity offerings. A return factor constructed by buying stocks with the lowest $30 \%$ investmentto-asset ratios and selling stocks with the highest $30 \%$ investment-to-asset ratios, while controlling for size and book-to-market, earns on average $0.37 \%$ per month with a highly significant $t$-statistic of 4.35. More importantly, adding this investment factor into standard factor regressions makes the SEO underperformance largely insignificant and reduces its magnitude by around $40 \%$. The reason is that equity issuers invest much more than matching nonissuers. In the year preceding issuance, the average investment-to-asset of issuers is 0.09 , $40 \%$ higher than that of nonissuers, 0.055 , the difference being highly significant.

Our evidence lends support to the investment-based models of SEO underperformance proposed by Carlson, Fisher, and Giammarino (2005) and Zhang (2005). Cochrane (1991, 1996) and Berk, Green, and Naik (1999) predict a negative relation between real investment and expected returns. Carlson et al. and Zhang argue that this negative relation can potentially drive the SEO underperformance because the balance-sheet constraint requires that the uses of funds must add up to the sources of funds. Issuers thus invest more and earn ex-ante lower rates of return than matching nonissuers.

We also document new evidence inconsistent with existing explanations based on overinvestment (e.g., Richardson and Sloan (2003)) and leverage (e.g., Eckbo, Masulis, and Norli (2000)). Inconsistent with the overinvestment theory, the negative investment-return relation is even stronger among firms with strong shareholder rights, manifested by low

turnover and trading volume, thereby lowering issuers' liquidity risk and expected returns required to compensate for that risk. Although this explanation is intuitive in the context of IPOs and SEOs, it is not clear how issuing debt, initiating or omitting dividends, and announcing bank loans should affect stock liquidity. But the evidence is again potentially consistent with our investment hypothesis, as discussed in Section 2. 
Gompers-Ishii-Metrick (2003) governance and Bebchuk-Cohen-Ferrell (2005) entrenchment indexes. In addition, SEO firms are less vulnerable to overinvestment by empire-building managers than matching nonissuers with similar size and book-to-market. Inconsistent with the leverage-based explanation of SEO underperformance, even after equity issuance, SEO firms have market and book leverage ratios higher than those of matching nonissuers.

As discussed in Section 2, the investment hypothesis in principle can be applied to other external financing anomalies including underperformance following IPOs, debt offerings, private placements of equity, and loan announcements, as well as overperformance following dividend initiations, tender offers, and open market share repurchases. The balance-sheet constraint implies that firms raising capital should invest more and earn lower expected returns, and that firms distributing capital should invest less and earn higher expected returns. We plan to test these predictions in the future. 


\section{References}

Abel, Andrew B., Avinash K. Dixit, Janice C. Eberly, and Robert S. Pindyck, 1996, Options, the value of capital, and investment, Quarterly Journal of Economics 111, 753777.

Anderson, Christopher W., and Luis Garcia-Feijóo, 2005, Empirical evidence on capital investment, growth options, and security returns, forthcoming, Journal of Finance.

Ball, Ray, and S.P. Kothari, 1989, Nonstationary expected returns: Implications for tests of market efficiency and serial correlation in returns, Journal of Financial Economics $25,51-74$.

Barber, Brad M., and John D. Lyon, 1997, Detecting long-run abnormal sock returns: The empirical power and specification of test statistics, Journal of Financial Economics 43, $341-372$.

Barberis, Nicholas, Ming Huang, and Tano Santos, 2001, Prospect theory and asset prices, Quarterly Journal of Economics 116, 1-53.

Bebchuk, Lucian and Alma Cohen, 2005, The costs of entrenched boards, Journal of Financial Economics 78, 409-433.

Bebchuk, Lucian, Alma Cohen, and Allen Ferrell, 2005, What matters in corporate governance? working paper, Harvard Law School.

Berk, Jonathan B, Richard C. Green, and Vasant Naik, 1999, Optimal investment, growth options, and security returns, Journal of Finance 54, 1153-1607.

Billett, Matthew T., Mark J. Flannery, and Jon A. Garfinkel, 2005, The long-run performance of firms following loan announcements, working paper, University of Iowa and University of Florida.

Brav, Alon and Paul A. Gompers, 1997, Myth or reality? The long-run underperformance of initial public offerings: evidence from venture and nonventure capital-backed companies, Journal of Finance 52, 1791-1812.

Brav, Alon, Christopher Geczy and Paul A. Gompers, 2000, Is the abnormal return following equity issuances anomalous?, Journal of Financial Economics 56, 209-249.

Brealey, Richard A., Stewart C. Myers, and Franklin Allen, 2006, Principles of corporate finance, $8^{\text {th }}$ edition, Irwin McGraw-Hill.

Butler, Alexander W., Gustavo Grullon and James P. Weston, 2005, Can managers forecast aggregate market returns?, Journal of Finance 60, 963-986.

Carhart, Mark M., 1997, On persistence in mutual funds performance, Journal of Finance $52,57-82$. 
Carlson, Murray, Adlai Fisher, and Ron Giammarino, 2004, Corporate investment and asset price dynamics: Implications for the cross section of returns, Journal of Finance 59, $2577-2603$.

Carlson, Murray, Adlai Fisher, and Ron Giammarino, 2005, Corporate investment and asset price dynamics: Implications for SEO event studies and long-run performance, forthcoming, Journal of Finance.

Chambers, Dennis, Ross Jennings, and Robert B. Thompson II, 2002, Excess returns to R\&D intensive firms, Review of Accounting Studies 7, 133-158.

Chan, Louis K. C., Joseph Lakonishok, and Theodore Sougiannis, 2001, The stock market valuation of research and development expenditures, Journal of Finance 56, 2431-2456.

Chu, Yangchun, 2005, R\&D, capital investment, and stock returns, working paper, University of Rochester.

Cochrane, John H., 1991, Production-based asset pricing and the link between stock returns and economic fluctuations, Journal of Finance 46, 209-237.

Cochrane, John H., 1996, A cross-sectional test of an investment-based asset pricing model, Journal of Political Economy 104, 572-621.

Core, John E., Wayne R. Guay, and Tjomme O. Rusticus, 2005, Does weak governance cause weak stock returns? An examination of firm operating performance and investors' expectations, forthcoming, Journal of Finance.

Eberhart, Allan C. and Akhtar Siddique, 2002, The long-term performance of corporate bonds (and stocks) following seasoned equity offerings, Review of Financial Studies 15, $1385-1406$.

Eckbo, B. Espen, Ronald W. Masulis and Øyvind Norli, 2000, Seasoned public offerings: Resolution of the "new issues puzzle," Journal of Financial Economics 56, 251-291.

Fama, Eugene F., 1998, Market efficiency, long-term returns, and behavioral finance, Journal of Financial Economics 49, 283-306.

Fama, Eugene F. and Kenneth R. French, 1992, The cross-section of expected stock returns, Journal of Finance 47, 427-466.

Fama, Eugene F. and Kenneth R. French, 1993, Common risk factors in the returns on stocks and bonds, Journal of Financial Economics 33, 3-56.

Fama, Eugene and James MacBeth, 1973, Risk, return, and equilibrium: empirical tests, Journal of Political Economy 81, 607-636.

Gompers, Paul A., Joy L. Ishii, and Andrew Metrick, 2003, Corporate governance and equity prices, Quarterly Journal of Economics 118, 107-155. 
Hertzel, Michael, Michael Lemmon, James Linck, and Lynn Rees, 2002, Long-run performance following private placements of equity, Journal of Finance 57, 2595-2617.

Ikenberry, David, Josef Lakonishok, and Theo Vermaelen, 1995, Market underreaction to open market share repurchases, Journal of Financial Economics 39, 181-208.

Kang, Jun-Koo, Yong-Cheol Kim, and René M. Stulz, 1999, The underreaction hypothesis and the new issues puzzle: evidence from Japan, Review of Financial Studies 12, 519534.

Kothari, S. P., and Jerold B. Warner, 1997, Measuring long-horizon security price performance, Journal of Financial Economics 43, 301-339.

Li, Qing, Maria Vassalou, and Yuhang Xing, 2004, Sector investment growth rates and the cross-section of equity returns, forthcoming, Journal of Business.

Lakonishok, Josef, and Theo Vermaelen, 1990, Anomalous price behavior around repurchase tender offers, Journal of Finance 45, 455-477.

Loughran, Tim and Jay R. Ritter, 1995, The new issues puzzle, Journal of Finance 50, $23-51$.

Loughran, Tim, and Jay R. Ritter, 1997, The operating performance of firms conducting seasoned equity offerings, Journal of Finance 52, 1823-1850.

Loughran, Tim, and Jay R. Ritter, 2000, Uniformly least powerful tests of market efficiency, Journal of Finance 55, 361-389.

Michaely, Roni, Richard H. Thaler, and Kent L. Womack, 1995, Price reactions to dividend initiations and omissions: overreaction or drift? Journal of Finance 50, 573-608.

Mitchell, Mark L. and Erik Stafford, 2000, Managerial decisions and long-term stock price performance, Journal of Business 73, 287-320.

Petkova, Ralitsa, and Lu Zhang, 2005, Is value riskier than growth? Journal of Financial Economics 78, 187-202.

Polk, Christopher, and Paola Sapienza, 2005, The real effects of investor sentiment, working paper, Northwestern University.

Richardson, Scott A., and Richard G. Sloan, 2003, External financing, capital investment, and future stock returns, working paper, The Wharton School, University of Pennsylvania.

Ritter, Jay R., 1991, The long-run performance of initial public offerings, Journal of Finance $46,3-27$.

Ritter, Jay R., 2003, Investment banking and securities issuance, in George Constantinides, Milton Harris, and René Stulz, eds.: Handbook of the Economics of Finance (NorthHolland, Amsterdam). 
Schultz, Paul, 2003, Pseudo market timing and the long-run underperformance of IPOs, Journal of Finance 58, 483-517.

Spiess, Katherine D., and John Affleck-Graves, 1995, Underperformance in long-run stock returns following seasoned equity offerings, Journal of Financial Economics 38, 243267.

Spiess, Katherine D., and John Affleck-Graves, 1999, The long run performance of stock returns following debt offerings, Journal of Financial Economics 54, 45-73.

Titman, Sheridan, K.C. John Wei, and Feixue Xie, 2004, Capital investments and stock returns, Journal of Financial and Quantitative Analysis 39, 677-700.

Viswanathan, S., and Bin Wei, 2004, Endogenous events and long run returns, working paper, Duke University.

White, Halbert L., Jr., 1980, A heteroscedasticity-consistent covariance matrix estimator and a direct test for heteroscedasticity, Econometrica 48, 817-838.

Xing, Yuhang, 2005, Interpreting the value effect through the $Q$-theory: an empirical investigation, working paper, Rice University.

Zhang, Lu, 2005, Anomalies, NBER working paper 11322. 


\section{Table 1 : The Number of Seasoned Equity Offerings}

This table reports the total number of SEOs sample in SDC by year (column 1), the number of SEOs that can be matched with CRSP by NCUSIP (column 2), by CUSIP (column 3), the number of SEO firms on NYSE (column 4), AMEX (column 5), and NASDAQ (column 6), the number of primary offerings (column 7), mixed offerings (column 8), the number of SEOs by non-utilities (column 9), non-financials (column 10), the number of SEOs by U.S. firms with common stocks on NYSE, AMEX, and NASDAQ with return data at some point during post-SEO period (column 11), and the number of firms from column 11 with valid market size, book-to-market, and investment data (column 12).

\begin{tabular}{|c|c|c|c|c|c|c|c|c|c|c|c|c|}
\hline Year & $\begin{array}{r}1 \\
\text { All } \\
\end{array}$ & $\begin{array}{r}2 \\
\text { NCUSIP } \\
\end{array}$ & $\begin{array}{r}3 \\
\text { CUSIP } \\
\end{array}$ & $\begin{array}{r}4 \\
\text { NYSE } \\
\end{array}$ & $\begin{array}{r}5 \\
\text { AMEX }\end{array}$ & $\begin{array}{r}6 \\
\text { NASD } \\
\end{array}$ & $\begin{array}{r}7 \\
\text { Prim } \\
\end{array}$ & $\begin{array}{r}8 \\
\text { Mix } \\
\end{array}$ & $\begin{array}{r}9 \\
\text { Non-Util } \\
\end{array}$ & $\begin{array}{r}10 \\
\text { Non-Fin } \\
\end{array}$ & $\begin{array}{r}11 \\
\text { US } \\
\end{array}$ & $\begin{array}{r}12 \\
\text { SEO-Inv } \\
\end{array}$ \\
\hline 1970 & 92 & 91 & 55 & 66 & 26 & 0 & 54 & 38 & 58 & 88 & 72 & 62 \\
\hline 1971 & 232 & 230 & 138 & 142 & 90 & 0 & 94 & 138 & 177 & 209 & 164 & 138 \\
\hline 1972 & 218 & 217 & 141 & 135 & 69 & 14 & 87 & 131 & 164 & 200 & 165 & 144 \\
\hline 1973 & 140 & 139 & 68 & 85 & 3 & 51 & 92 & 48 & 76 & 129 & 101 & 85 \\
\hline 1974 & 82 & 81 & 33 & 62 & 2 & 17 & 65 & 17 & 30 & 81 & 68 & 63 \\
\hline 1975 & 178 & 178 & 87 & 136 & 5 & 37 & 130 & 48 & 78 & 174 & 135 & 129 \\
\hline 1976 & 190 & 187 & 112 & 123 & 17 & 50 & 130 & 60 & 101 & 183 & 150 & 137 \\
\hline 197 & 134 & 133 & 71 & 87 & 7 & 40 & 94 & 40 & 63 & 131 & 100 & 98 \\
\hline 197 & 179 & 178 & 101 & 104 & 14 & 61 & 127 & 52 & 105 & 66 & 143 & 128 \\
\hline 197 & 160 & 159 & 96 & 84 & 19 & 56 & 117 & 43 & 92 & 155 & 118 & 109 \\
\hline 198 & 319 & 317 & 208 & 158 & 41 & 120 & 227 & 92 & 229 & 308 & 244 & 223 \\
\hline 1981 & 337 & 336 & 212 & 168 & 32 & 136 & 231 & 106 & 253 & 309 & 258 & 208 \\
\hline 1982 & 361 & 360 & 232 & 235 & 27 & 99 & 194 & 167 & 67 & 328 & 279 & 234 \\
\hline 1 & 661 & 6 & 5 & 296 & 80 & 285 & 348 & 313 & 87 & 91 & 510 & 436 \\
\hline 198 & 202 & 201 & $1:$ & 92 & 18 & 92 & 118 & 84 & 72 & 155 & 140 & 106 \\
\hline 198 & 323 & 322 & 243 & 99 & 38 & 186 & 189 & 134 & 297 & 231 & 217 & 147 \\
\hline 19 & 414 & 413 & 300 & 106 & 48 & 260 & 248 & 166 & 90 & 275 & 278 & 195 \\
\hline 1987 & 236 & 234 & 185 & 89 & 31 & 116 & 157 & 79 & 224 & 183 & 168 & 111 \\
\hline 19 & 114 & 1 & 92 & 39 & 20 & 55 & 70 & 44 & 01 & 90 & 88 & 64 \\
\hline & 1 & 1 & 146 & 50 & 29 & 114 & 116 & 77 & 2 & 152 & 153 & 111 \\
\hline $19 !$ & 148 & 148 & 114 & 54 & 21 & 73 & 82 & 66 & 35 & 122 & 117 & 86 \\
\hline 199 & 416 & 410 & 323 & 154 & 43 & 219 & 260 & 156 & 384 & 349 & 339 & 244 \\
\hline 19 & 42 & 420 & & 173 & 49 & 199 & 261 & 160 & 87 & 16 & 330 & 216 \\
\hline 1993 & 622 & 618 & 495 & 241 & 45 & 334 & 362 & 260 & 77 & 55 & 469 & 309 \\
\hline 1994 & 389 & 7 & 327 & 176 & 23 & 189 & 224 & 165 & 72 & 99 & 263 & 190 \\
\hline 19 & 5 & 5 & 444 & 1 & 22 & 328 & 277 & 261 & 7 & 428 & 394 & 275 \\
\hline 190 & 674 & 671 & 552 & 2 & 27 & 401 & 337 & 337 & 660 & 527 & 493 & 335 \\
\hline 19 & 6 & 651 & 5 & 272 & 36 & 346 & 362 & 293 & 42 & 459 & 436 & 299 \\
\hline $19 !$ & 498 & 496 & 435 & 252 & 25 & 221 & 301 & 197 & 477 & 319 & 312 & 215 \\
\hline 1999 & 403 & 402 & 364 & 126 & 11 & 265 & 191 & 212 & 396 & 356 & 319 & 201 \\
\hline 2000 & 355 & 355 & 328 & 87 & 10 & 258 & 176 & 179 & 344 & 332 & 306 & 208 \\
\hline 200 & 37 & 374 & 361 & 194 & 20 & 160 & 220 & 154 & 355 & 246 & 249 & 197 \\
\hline & 38 & & & 225 & 13 & 147 & 267 & 118 & 356 & 275 & 255 & 194 \\
\hline 2003 & 449 & 449 & 442 & 252 & 19 & 178 & 314 & 135 & 423 & 308 & 293 & 225 \\
\hline All & 092 & 036 & 610 & 4,996 & 980 & 5,107 & 6,522 & 4,570 & 9,661 & 8,929 & 8,126 & 6,122 \\
\hline
\end{tabular}




\section{Table 2 : Calendar-Time Factor Regressions of SEO portfolio Excess Returns (January 1970 to December 2003)}

This table reports calendar-time factor regressions of SEO portfolio excess returns. The portfolios consist of firms that have conducted SEOs during 36 months (Panel A) and 60 months (Panel B) prior to the month of portfolio formation. We use two factor models, the CAPM and the Fama and French (1993) three-factor model. We obtain the factor returns, MKT, SMB, and HML from Kenneth French's website. The $t$-statistics reported in parentheses are computed using White (1980) heteroscedasticity-consistent standard errors.

\begin{tabular}{|c|c|c|c|c|}
\hline & \multicolumn{4}{|c|}{ Panel A: Prior 36-month SEO portfolios } \\
\hline & \multicolumn{2}{|c|}{ Equally-weighted returns } & \multicolumn{2}{|c|}{ Value-weighted returns } \\
\hline & CAPM & Fama-French & CAPM & Fama-French \\
\hline$\alpha$ & $\begin{array}{l}-0.279 \\
(-1.91) \\
\end{array}$ & $\begin{array}{l}-0.291 \\
(-2.89) \\
\end{array}$ & $\begin{array}{l}-0.356 \\
(-3.56) \\
\end{array}$ & $\begin{array}{l}-0.280 \\
(-2.92) \\
\end{array}$ \\
\hline MKT & $\begin{array}{r}1.282 \\
(33.96)\end{array}$ & $\begin{array}{r}1.131 \\
(33.90)\end{array}$ & $\begin{array}{r}1.124 \\
(36.23)\end{array}$ & $\begin{array}{r}1.084 \\
(35.86)\end{array}$ \\
\hline SMB & & $\begin{array}{r}0.714 \\
(13.64)\end{array}$ & & $\begin{array}{r}0.015 \\
(0.36)\end{array}$ \\
\hline HML & & $\begin{array}{r}-0.049 \\
(-0.92) \\
\end{array}$ & & $\begin{array}{r}-0.121 \\
(-2.08) \\
\end{array}$ \\
\hline \multirow[t]{4}{*}{$\operatorname{Adj}-R^{2}$} & 0.799 & 0.921 & 0.885 & 0.888 \\
\hline & \multicolumn{4}{|c|}{ Panel B: Prior 60-month SEO portfolios } \\
\hline & \multicolumn{2}{|c|}{ Equally-weighted returns } & \multicolumn{2}{|c|}{ Value-weighted returns } \\
\hline & CAPM & Fama-French & CAPM & Fama-French \\
\hline$\alpha$ & $\begin{array}{c}-0.114 \\
(-0.79) \\
\end{array}$ & $\begin{array}{l}-0.208 \\
(-2.29) \\
\end{array}$ & $\begin{array}{l}-0.249 \\
(-2.84) \\
\end{array}$ & $\begin{array}{r}-0.205 \\
(-2.56) \\
\end{array}$ \\
\hline MKT & $\begin{array}{r}1.259 \\
(32.60)\end{array}$ & $\begin{array}{r}1.134 \\
(36.43)\end{array}$ & $\begin{array}{r}1.116 \\
(30.19)\end{array}$ & $\begin{array}{r}1.090 \\
(46.24)\end{array}$ \\
\hline SMB & & $\begin{array}{r}0.776 \\
(16.98)\end{array}$ & & $\begin{array}{r}0.023 \\
(0.69)\end{array}$ \\
\hline HML & & $\begin{array}{r}0.076 \\
(1.65) \\
\end{array}$ & & $\begin{array}{r}-0.071 \\
(-1.46) \\
\end{array}$ \\
\hline $\mathrm{Adj}-R^{2}$ & 0.792 & 0.932 & 0.915 & 0.917 \\
\hline
\end{tabular}


Table 3 : Calendar-Time Factor Regressions of SEO Portfolio Excess Returns onto the Eckbo-Masulis-Norli (2000) Six-Factor Model (January 1970 to December 2002)

This table reports calendar-time factor regressions of portfolios consisting of firms that have conducted SEOs during 36 months (Panel A) and 60 months (Panel B) prior to the month of portfolio formation. The model of normal returns is the Eckbo-Masulis-Norli (2000) six-factor model. The sample period is from January 1970 to December 2002 because the data of the six factors from Øyvind Norli end at December 2002. The factors are as follows. RM is the excess return on the CRSP value-weighted market index. $\triangle \mathrm{RPC}$ is a factor mimicking portfolio for the percent change in the real per capita consumption of nondurable goods. BAA-AAA is a factor mimicking portfolio for the difference in the monthly yield changes on bonds rated BAA and AAA by Moody's. UI is a factor mimicking portfolio for unanticipated inflation generated from a model of expected inflation involving a regression of real returns (returns on 30-day Treasury bills less inflation) on a 12 of its lagged values and a constant. $20 \mathrm{y}-1 \mathrm{y}$ is the return difference between Treasury bonds with 20 years to maturity and Treasury bonds with one year to maturity. TBILLspr is the return difference between 90-day and 30-day Treasury bills. The $t$-statistics reported in parentheses are computed using White (1980) heteroscedasticity-consistent standard errors.

\begin{tabular}{|c|c|c|c|c|}
\hline & \multicolumn{2}{|c|}{ Panel A: Prior 36-month SEOs } & \multicolumn{2}{|c|}{ Panel B: Prior 60-month SEOs } \\
\hline & Equally-weighted & Value-weighted & Equally-weighted & Value-weighted \\
\hline$\alpha$ & $\begin{array}{l}-0.515 \\
(-3.22) \\
\end{array}$ & $\begin{array}{l}-0.359 \\
(-3.38)\end{array}$ & $\begin{array}{l}-0.413 \\
(-2.68)\end{array}$ & $\begin{array}{l}-0.263 \\
(-3.00)\end{array}$ \\
\hline $\mathrm{RM}$ & $\begin{array}{r}1.297 \\
(35.08)\end{array}$ & $\begin{array}{r}1.112 \\
(37.60)\end{array}$ & $\begin{array}{r}1.271 \\
(36.26)\end{array}$ & $\begin{array}{r}1.105 \\
(46.00)\end{array}$ \\
\hline$\triangle \mathrm{RPC}$ & $\begin{array}{r}1.121 \\
(3.17)\end{array}$ & $\begin{array}{r}0.261 \\
(1.47)\end{array}$ & $\begin{array}{r}1.296 \\
(3.42)\end{array}$ & $\begin{array}{r}0.147 \\
(0.97)\end{array}$ \\
\hline $\mathrm{BAA}-\mathrm{AAA}$ & $\begin{array}{l}-0.062 \\
(-0.18)\end{array}$ & $\begin{array}{l}0.451 \\
(2.60)\end{array}$ & $\begin{array}{l}-0.193 \\
(-0.61)\end{array}$ & $\begin{array}{l}0.411 \\
(2.82)\end{array}$ \\
\hline UI & $\begin{array}{l}5.195 \\
(2.45)\end{array}$ & $\begin{array}{l}-3.572 \\
(-2.96)\end{array}$ & $\begin{array}{l}7.949 \\
(3.95)\end{array}$ & $\begin{array}{l}-3.100 \\
(-3.15)\end{array}$ \\
\hline$(20 y-1 y) / 100$ & $\begin{array}{l}-0.201 \\
(-3.23)\end{array}$ & $\begin{array}{l}-0.029 \\
(-0.68)\end{array}$ & $\begin{array}{l}-0.185 \\
(-3.03)\end{array}$ & $\begin{array}{l}-0.028 \\
(-0.81)\end{array}$ \\
\hline TBillSpr/100 & $\begin{array}{r}2.815 \\
(1.87) \\
\end{array}$ & $\begin{array}{r}1.517 \\
(1.58) \\
\end{array}$ & $\begin{array}{r}2.756 \\
(1.85) \\
\end{array}$ & $\begin{array}{r}1.368 \\
(1.80) \\
\end{array}$ \\
\hline $\operatorname{Adj}-R^{2}$ & 0.814 & 0.896 & 0.820 & 0.923 \\
\hline
\end{tabular}




\section{Table 4 : Explaining the Investment Factor with the CAPM and the Fama-French (1993) Three-Factor Model (January 1970 to December 2003) and with the Eckbo-Masulis-Norli (2000) Six-Factor Model (January 1970 to December 2002)}

This table reports calendar-time factor regressions of the investment factor using the CAPM, the FamaFrench (1993) three-factor model, and the Eckbo-Masulis-Norli (2000) six-factor model. We construct the investment factor from a triple sort on size, book-to-market, and investment-to-asset ratio. Investment-toasset ratio is measured as the annual change in gross property, plant and equipment (Compustat annual item 7) divided by the lagged book value of assets (item 6). In June of each year, we sort all stocks in ascending order independently on size, book-to-market, and investment-to-asset ratio into three groups, the top $30 \%$, the medium $40 \%$, and the bottom $30 \%$. The investment factor is defined as the average lowinvestment portfolio minus the average high-investment portfolio. The factor returns, MKT, SMB, and HML are obtained from Kenneth French's website. The EMN six factors are from Øyvind Norli and are as follows. $\mathrm{RM}$ is the excess return on the CRSP value-weighted market index. $\triangle \mathrm{RPC}$ is a factor mimicking portfolio for the percent change in the real per capita consumption of nondurable goods. BAA-AAA is a factor mimicking portfolio for the difference in the monthly yield changes on bonds rated BAA and AAA by Moody's. UI is a factor mimicking portfolio for unanticipated inflation generated from a model of expected inflation involving a regression of real returns (returns on 30-day Treasury bills less inflation) on a constant and 12 of its lagged values. $20 \mathrm{y}-1 \mathrm{y}$ is the return difference between Treasury bonds with 20 years to maturity and Treasury bonds with one year to maturity. TBILLspr is the return difference between 90day and 30-day Treasury bills. The $t$-statistics reported in parentheses are computed using White (1980) heteroscedasticity-consistent standard errors.

\begin{tabular}{|c|c|c|c|c|}
\hline & $\mathrm{CAPM}$ & Fama-French & & EMN \\
\hline$\alpha$ & $\begin{array}{r}0.397 \\
(4.88)\end{array}$ & $\begin{array}{r}0.268 \\
(3.33)\end{array}$ & $\alpha$ & $\begin{array}{r}0.282 \\
(3.06)\end{array}$ \\
\hline MKT & $\begin{array}{r}-0.040 \\
(-2.09)\end{array}$ & $\begin{array}{r}0.006 \\
(0.34)\end{array}$ & $\mathrm{RM}$ & $\begin{array}{l}-0.054 \\
(-2.88)\end{array}$ \\
\hline SMB & & $\begin{array}{r}0.076 \\
(2.75)\end{array}$ & $\triangle \mathrm{RPC}$ & $\begin{array}{r}0.035 \\
(0.18)\end{array}$ \\
\hline \multirow[t]{3}{*}{ HML } & & $\begin{array}{r}0.198 \\
(6.75)\end{array}$ & $\mathrm{BAA}-\mathrm{AAA}$ & $\begin{array}{l}-0.114 \\
(-0.87)\end{array}$ \\
\hline & & & $(20 y-1 y) / 100$ & $\begin{array}{l}0.119 \\
(3.57)\end{array}$ \\
\hline & & & TBillSpr/100 & $\begin{array}{r}1.154 \\
(1.36) \\
\end{array}$ \\
\hline $\operatorname{Adj}-R^{2}$ & 0.011 & 0.124 & & 0.089 \\
\hline
\end{tabular}




\section{Table 5 : Calendar-Time Factor Regressions Augmented with the Investment Factor (January 1970 to December 2003)}

This table reports calendar-time factor regressions of excess returns of portfolios consisting of firms that have conducted SEOs during 36 months (Panel A) and 60 months (Panel B) prior to the month of portfolio formation. We augment the CAPM and the Fama and French (1993) three-factor model with the investment factor, denoted INV. We obtain the factor returns MKT, SMB, and HML from Kenneth French's website. We construct INV from a triple sort on size, book-to-market, and investment-to-asset ratio. Specifically, investment-to-asset ratio is measured as the annual change in gross property, plant and equipment (Compustat annual item 7) divided by the lagged book value of assets (item 6). In June of each year, we sort all stocks in ascending order independently on size, book-to-market, and investment-to-asset ratio into three groups, the top $30 \%$, the medium $40 \%$, and the bottom $30 \%$. The investment factor is defined as the average low-investment portfolio minus the average high-investment portfolio. The $t$-statistics reported in parentheses are computed using White (1980) heteroscedasticity-consistent standard errors. $|\triangle \alpha| /|\alpha|$ denotes the reduction of alphas from using the investment factor as an additional explanatory variable divided by the magnitudes of the alphas from the CAPM and the Fama-French three-factor model reported in Table 2.

\begin{tabular}{|c|c|c|c|c|}
\hline & \multicolumn{4}{|c|}{ Panel A: Prior 36-month SEO portfolios } \\
\hline & \multicolumn{2}{|c|}{ Equally-weighted returns } & \multicolumn{2}{|c|}{ Value-weighted returns } \\
\hline & CAPM & Fama-French & CAPM & Fama-French \\
\hline$\alpha$ & $\begin{array}{l}-0.151 \\
(-0.94) \\
\end{array}$ & $\begin{array}{l}-0.166 \\
(-1.62) \\
\end{array}$ & $\begin{array}{r}-0.195 \\
(-2.12) \\
\end{array}$ & $\begin{array}{r}-0.177 \\
(1.90) \\
\end{array}$ \\
\hline MKT & $\begin{array}{r}1.270 \\
(34.21)\end{array}$ & $\begin{array}{r}1.134 \\
(36.94)\end{array}$ & $\begin{array}{r}1.108 \\
(40.64)\end{array}$ & $\begin{array}{r}1.087 \\
(38.12)\end{array}$ \\
\hline SMB & & $\begin{array}{r}0.749 \\
(15.04)\end{array}$ & & $\begin{array}{c}0.044 \\
(1.19)\end{array}$ \\
\hline HML & & $\begin{array}{r}0.043 \\
(0.90)\end{array}$ & & $\begin{array}{l}-0.044 \\
(-0.82)\end{array}$ \\
\hline INV & $\begin{array}{l}-0.323 \\
(-2.51) \\
\end{array}$ & $\begin{array}{l}-0.465 \\
(-5.84) \\
\end{array}$ & $\begin{array}{r}-0.405 \\
(-5.36) \\
\end{array}$ & $\begin{array}{r}-0.388 \\
(-5.91) \\
\end{array}$ \\
\hline$|\triangle \alpha| /|\alpha|$ & 0.459 & 0.430 & 0.452 & 0.368 \\
\hline \multirow[t]{4}{*}{$\operatorname{Adj}-R^{2}$} & 0.804 & 0.931 & 0.898 & 0.899 \\
\hline & \multicolumn{4}{|c|}{ Panel B: Prior 60-month SEO portfolios } \\
\hline & \multicolumn{2}{|c|}{ Equally-weighted returns } & \multicolumn{2}{|c|}{ Value-weighted returns } \\
\hline & CAPM & Fama-French & CAPM & Fama-French \\
\hline$\alpha$ & $\begin{array}{l}-0.066 \\
(-0.41) \\
\end{array}$ & $\begin{array}{l}-0.122 \\
(-1.27) \\
\end{array}$ & $\begin{array}{l}-0.137 \\
(-1.46) \\
\end{array}$ & $\begin{array}{l}-0.131 \\
(-1.65) \\
\end{array}$ \\
\hline MKT & $\begin{array}{r}1.254 \\
(32.48)\end{array}$ & $\begin{array}{r}1.136 \\
(38.37)\end{array}$ & $\begin{array}{r}1.105 \\
(48.92)\end{array}$ & $\begin{array}{r}1.092 \\
(48.68)\end{array}$ \\
\hline SMB & & $\begin{array}{r}0.800 \\
(18.08)\end{array}$ & & $\begin{array}{r}0.044 \\
(1.43)\end{array}$ \\
\hline HML & & $\begin{array}{r}0.140 \\
(3.17)\end{array}$ & & $\begin{array}{l}-0.016 \\
(-0.35)\end{array}$ \\
\hline INV & $\begin{array}{l}-0.120 \\
(-0.96) \\
\end{array}$ & $\begin{array}{r}-0.322 \\
(-4.25) \\
\end{array}$ & $\begin{array}{r}-0.280 \\
(-4.30) \\
\end{array}$ & $\begin{array}{r}-0.278 \\
(-4.85) \\
\end{array}$ \\
\hline$|\triangle \alpha| /|\alpha|$ & 0.421 & 0.414 & 0.450 & 0.361 \\
\hline $\operatorname{Adj}-R^{2}$ & 0.792 & 0.937 & 0.922 & 0.923 \\
\hline
\end{tabular}


Table 6 : Calendar-Time Factor Regressions of SEO Portfolios onto Issuer-Purged Fama-French Factors and the Purged and Unpurged Investment Factors (January 1975 to December 2003)

This table reports calendar-time factor regressions with and without the investment factor (both purged and unpurged of SEO firms). The dependent variables are equally-weighted and value-weighted portfolio excess returns of firms that have conducted SEOs during 36 months (Panel A) and during 60 months (Panel B) prior to the month of portfolio formation. The size and book-to-market factors used in the regressions, denoted pSMB and pHML respectively, are purged of firms that have issued new equity within the previous five years. The data of pSMB and pHML are from Jay Ritter. The issuer-purged investment factor, denoted pINV, is also purged of firms that have issued new equity within the previous 60 months. The sample starts at January 1975 because we purge firms with prior 60-month SEOs. We also report factor regressions with pSMB, pHML, and unpurged investment factor, denoted INV. We construct pINV and INV by triple sorting on size, book-to-market, and investment-to-asset. Specifically, investment-to-asset is measured as the annual change in gross property, plant and equipment (Compustat annual item 7) divided by the lagged book value of assets (item 6). In June of each year, we sort all stocks in ascending order independently on size, book-to-market, and investment-to-asset ratio into three groups, the top $30 \%$, the medium $40 \%$, and the bottom $30 \%$. The investment factor is defined as the average low-investment portfolio minus the average high-investment portfolio. The $t$-statistics reported in parentheses are computed using White (1980) heteroscedasticity-consistent standard errors. $|\triangle \alpha| /|\alpha|$ denotes the reduction of alphas from adding the investment factor (purged and unpurged) divided by the magnitudes of the alphas from the purged Fama-French (1993) factor regressions.

\begin{tabular}{|c|c|c|c|c|c|c|c|c|c|c|c|c|}
\hline \multirow[b]{3}{*}{$\alpha$} & \multicolumn{6}{|c|}{ Panel A: Prior 36-month SEO portfolio } & \multicolumn{6}{|c|}{ Panel B: Prior 60-month SEO portfolio } \\
\hline & \multicolumn{3}{|c|}{ Equally-weighted } & \multicolumn{3}{|c|}{ Value-weighted } & \multicolumn{3}{|c|}{ Equally-weighted } & \multicolumn{3}{|c|}{ Value-weighted } \\
\hline & $\begin{array}{l}-0.393 \\
(-3.28) \\
\end{array}$ & $\begin{array}{l}-0.253 \\
(-2.11) \\
\end{array}$ & $\begin{array}{l}-0.201 \\
(-1.74) \\
\end{array}$ & $\begin{array}{l}-0.334 \\
(-2.85) \\
\end{array}$ & $\begin{array}{c}-0.256 \\
(-2.26) \\
\end{array}$ & $\begin{array}{l}-0.190 \\
(-1.74) \\
\end{array}$ & $\begin{array}{l}-0.276 \\
(-2.50) \\
\end{array}$ & $\begin{array}{l}-0.174 \\
(-1.50) \\
\end{array}$ & $\begin{array}{l}-0.137 \\
(-1.21) \\
\end{array}$ & $\begin{array}{r}-0.230 \\
(-2.39) \\
\end{array}$ & $\begin{array}{r}-0.178 \\
(-1.89) \\
\end{array}$ & $\begin{array}{l}-0.126 \\
(-1.38) \\
\end{array}$ \\
\hline MKT & $\begin{array}{r}1.183 \\
(30.53)\end{array}$ & $\begin{array}{r}1.173 \\
(31.96)\end{array}$ & $\begin{array}{r}1.180 \\
(34.70)\end{array}$ & $\begin{array}{r}1.095 \\
(30.30)\end{array}$ & $\begin{array}{r}1.089 \\
(31.10)\end{array}$ & $\begin{array}{r}1.092 \\
(32.85)\end{array}$ & $\begin{array}{r}1.181 \\
(31.27)\end{array}$ & $\begin{array}{r}1.173 \\
(31.96)\end{array}$ & $\begin{array}{r}1.178 \\
(33.61)\end{array}$ & $\begin{array}{r}1.097 \\
(38.56)\end{array}$ & $\begin{array}{r}1.093 \\
(39.46)\end{array}$ & $\begin{array}{r}1.095 \\
(41.17)\end{array}$ \\
\hline $\mathrm{pSMB}$ & $\begin{array}{r}0.790 \\
(14.49)\end{array}$ & $\begin{array}{r}0.818 \\
(16.17)\end{array}$ & $\begin{array}{r}0.837 \\
(17.67)\end{array}$ & $\begin{array}{r}0.049 \\
(0.99)\end{array}$ & $\begin{array}{l}0.065 \\
(1.35)\end{array}$ & $\begin{array}{r}0.085 \\
(1.92)\end{array}$ & $\begin{array}{r}0.856 \\
(16.57)\end{array}$ & $\begin{array}{r}0.876 \\
(17.84)\end{array}$ & $\begin{array}{r}0.890 \\
(18.98)\end{array}$ & $\begin{array}{r}0.570 \\
(1.40)\end{array}$ & $\begin{array}{l}0.067 \\
(1.71)\end{array}$ & $\begin{array}{c}0.082 \\
(2.23)\end{array}$ \\
\hline pHML & $\begin{array}{l}-0.140 \\
(-1.99)\end{array}$ & $\begin{array}{l}-0.038 \\
(-0.61)\end{array}$ & $\begin{array}{l}-0.017 \\
(-0.29)\end{array}$ & $\begin{array}{l}-0.113 \\
(-1.61)\end{array}$ & $\begin{array}{l}-0.057 \\
(-0.85)\end{array}$ & $\begin{array}{l}-0.021 \\
(-0.34)\end{array}$ & $\begin{array}{l}0.003 \\
(0.05)\end{array}$ & $\begin{array}{r}0.077 \\
(1.32)\end{array}$ & $\begin{array}{r}0.092 \\
(1.59)\end{array}$ & $\begin{array}{l}-0.062 \\
(-1.07)\end{array}$ & $\begin{array}{l}-0.024 \\
(-0.44)\end{array}$ & $\begin{array}{l}0.004 \\
(0.08)\end{array}$ \\
\hline pINV & & $\begin{array}{l}-0.482 \\
(-5.54)\end{array}$ & & & $\begin{array}{l}-0.267 \\
(-3.27)\end{array}$ & & & $\begin{array}{l}-0.349 \\
(-4.24)\end{array}$ & & & $\begin{array}{l}-0.179 \\
(-2.53)\end{array}$ & \\
\hline INV & & & $\begin{array}{l}-0.624 \\
(-7.72) \\
\end{array}$ & & & $\begin{array}{l}-0.467 \\
(-6.47) \\
\end{array}$ & & & $\begin{array}{l}-0.451 \\
(-5.77) \\
\end{array}$ & & & $\begin{array}{l}-0.337 \\
(-5.39) \\
\end{array}$ \\
\hline$|\triangle \alpha| /|\alpha|$ & & 0.356 & 0.489 & & 0.234 & 0.431 & & 0.370 & 0.504 & & 0.226 & 0.452 \\
\hline $\operatorname{Adj}-R^{2}$ & 0.909 & 0.923 & 0.930 & 0.873 & 0.878 & 0.890 & 0.919 & 0.926 & 0.930 & 0.908 & 0.911 & 0.917 \\
\hline
\end{tabular}




\section{Table 7 : Event-Time Factor Regressions, Equally-Weighted SEO Portfolios (January 1970 to December 2003)}

This table reports event-time factor regressions of equally-weighted portfolios consisting of SEO firms for three years after the event. Panel A uses factor models including the CAPM and the Fama and French (1993) three-factor model. We obtain the factor returns MKT, SMB, and HML from Kenneth French's website. Panel B augments the factor models in Panel A with the investment factor, INV. We construct INV from a triple sort on size, book-to-market, and investment-to-asset ratio. Specifically, investment-toasset is measured as the annual change in gross property, plant and equipment (Compustat annual item 7) divided by the lagged book value of assets (item 6). In June of each year, we sort all stocks in ascending order independently on size, book-to-market, and investment-to-asset ratio into three groups, the top $30 \%$, the medium $40 \%$, and the bottom $30 \%$. The investment factor is defined as the average low-investment portfolio minus the average high-investment portfolio. The $t$-statistics reported in parentheses are computed using White (1980) heteroscedasticity-consistent standard errors. $|\triangle \alpha| /|\alpha|$ reported in Panel B denotes the reduction of alphas from using the investment factor as an additional explanatory variable divided by the magnitudes of the corresponding alphas without using the investment factor reported in Panel A. We do not report this ratio when the alpha after adding the investment factor becomes positive.

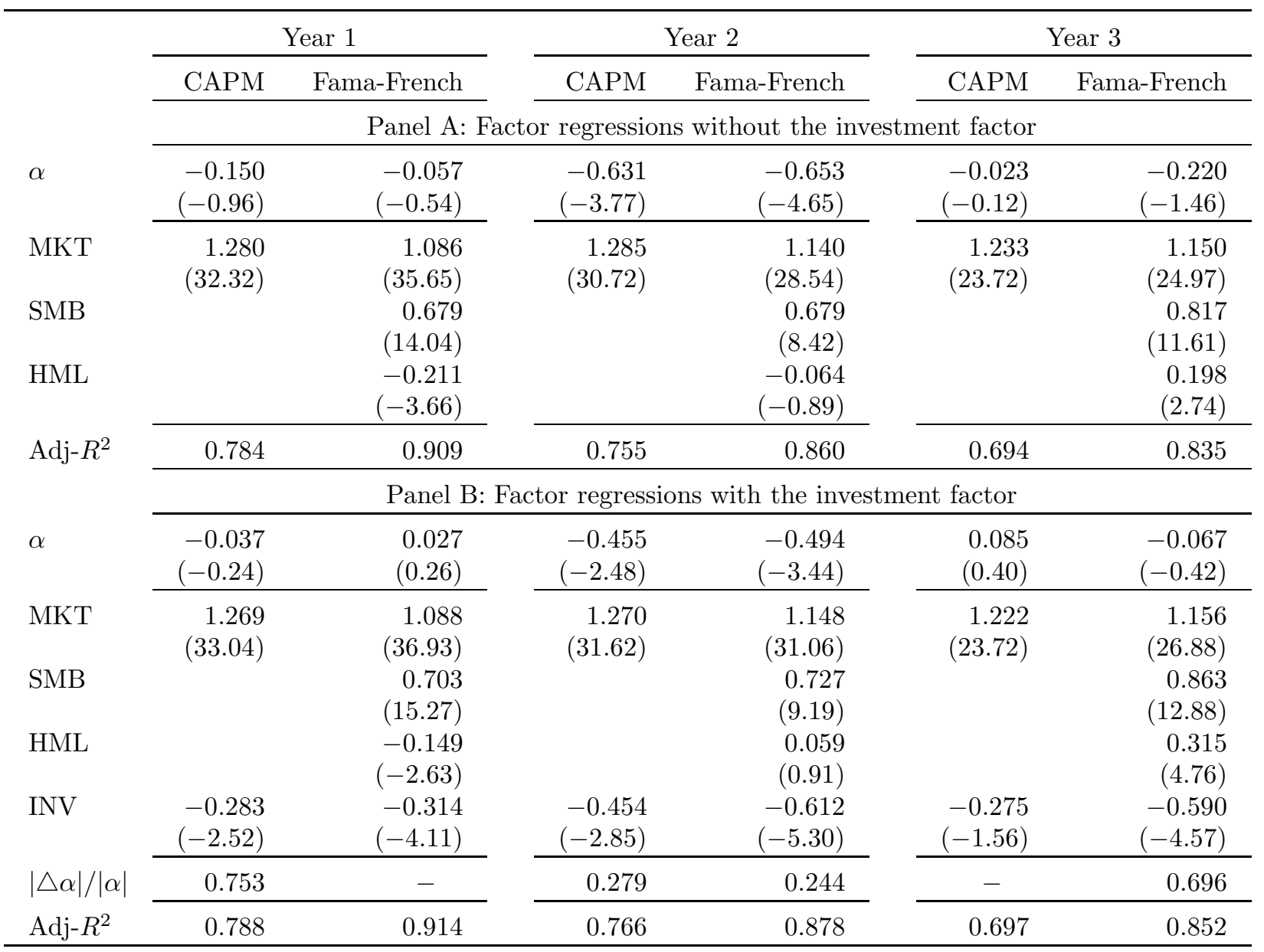




\section{Table 8 : Event-Time Factor Regressions, Value-Weighted SEO Portfolios (January 1970 to December 2003)}

This table reports event-time factor regressions of value-weighted portfolios consisting of SEO firms for three years after the event. Panel A uses factor models including the CAPM and the Fama and French (1993) threefactor model. We obtain the factor returns MKT, SMB, and HML from Kenneth French's website. Panel $\mathrm{B}$ augments the factor models in Panel A with the investment factor, INV. We construct INV from a triple sort on size, book-to-market, and investment-to-asset ratio. Specifically, investment-to-asset is measured as the annual change in gross property, plant and equipment (Compustat annual item 7) divided by the lagged book value of assets (item 6). In June of each year, we sort all stocks in ascending order independently on size, book-to-market, and investment-to-asset ratio into three groups, the top 30\%, the medium $40 \%$, and the bottom $30 \%$. The investment factor is defined as the average low-investment portfolio minus the average high-investment portfolio. The $t$-statistics reported in parentheses are computed using White (1980) heteroscedasticity-consistent standard errors. $|\triangle \alpha| /|\alpha|$ reported in Panel B denotes the reduction of alphas from using the investment factor as an additional explanatory variable divided by the magnitudes of the corresponding alphas without using the investment factor reported in Panel A.

\begin{tabular}{|c|c|c|c|c|c|c|}
\hline & \multicolumn{2}{|c|}{ Year 1} & \multicolumn{2}{|c|}{ Year 2} & \multicolumn{2}{|c|}{ Year 3} \\
\hline & CAPM & Fama-French & CAPM & Fama-French & CAPM & Fama-French \\
\hline & \multicolumn{6}{|c|}{ Panel A: Factor regressions without the investment factor } \\
\hline$\alpha$ & $\begin{array}{l}-0.298 \\
(-2.52) \\
\end{array}$ & $\begin{array}{l}-0.240 \\
(-2.07) \\
\end{array}$ & $\begin{array}{r}-0.602 \\
(-4.30) \\
\end{array}$ & $\begin{array}{l}-0.500 \\
(-3.57) \\
\end{array}$ & $\begin{array}{l}-0.141 \\
(-1.09) \\
\end{array}$ & $\begin{array}{l}-0.185 \\
(-1.36) \\
\end{array}$ \\
\hline MKT & $\begin{array}{r}1.099 \\
(31.30)\end{array}$ & $\begin{array}{r}1.055 \\
(28.66)\end{array}$ & $\begin{array}{r}1.141 \\
(26.56)\end{array}$ & $\begin{array}{r}1.084 \\
(26.03)\end{array}$ & $\begin{array}{r}1.127 \\
(32.91)\end{array}$ & $\begin{array}{r}1.151 \\
(29.26)\end{array}$ \\
\hline SMB & & $\begin{array}{r}0.072 \\
(1.43)\end{array}$ & & $\begin{array}{r}0.021 \\
(0.33)\end{array}$ & & $\begin{array}{l}-0.011 \\
(-0.19)\end{array}$ \\
\hline HML & & $\begin{array}{r}-0.098 \\
(-1.38) \\
\end{array}$ & & $\begin{array}{l}-0.171 \\
(-2.03) \\
\end{array}$ & & $\begin{array}{r}0.070 \\
(1.17) \\
\end{array}$ \\
\hline \multirow[t]{2}{*}{$\operatorname{Adj}-R^{2}$} & 0.831 & 0.835 & 0.796 & 0.802 & 0.812 & 0.812 \\
\hline & \multicolumn{6}{|c|}{ Panel B: Factor regressions with the investment factor } \\
\hline$\alpha$ & $\begin{array}{r}-0.150 \\
(-1.34) \\
\end{array}$ & $\begin{array}{r}-0.140 \\
(-1.22) \\
\end{array}$ & $\begin{array}{l}-0.414 \\
(-2.97) \\
\end{array}$ & $\begin{array}{l}-0.384 \\
(-2.70) \\
\end{array}$ & $\begin{array}{l}-0.074 \\
(-0.56) \\
\end{array}$ & $\begin{array}{l}-0.124 \\
(-0.90) \\
\end{array}$ \\
\hline MKT & $\begin{array}{r}1.084 \\
(33.36)\end{array}$ & $\begin{array}{r}1.058 \\
(30.06)\end{array}$ & $\begin{array}{r}1.125 \\
(29.17)\end{array}$ & $\begin{array}{r}1.090 \\
(27.10)\end{array}$ & $\begin{array}{r}1.120 \\
(33.76)\end{array}$ & $\begin{array}{r}1.154 \\
(29.43)\end{array}$ \\
\hline SMB & & $\begin{array}{r}0.100 \\
(2.14)\end{array}$ & & $\begin{array}{r}0.056 \\
(0.91)\end{array}$ & & $\begin{array}{r}0.008 \\
(0.15)\end{array}$ \\
\hline HML & & $\begin{array}{l}-0.024 \\
(-0.36)\end{array}$ & & $\begin{array}{l}-0.081 \\
(-1.03)\end{array}$ & & $\begin{array}{r}0.117 \\
(1.91)\end{array}$ \\
\hline INV & $\begin{array}{r}-0.372 \\
(-4.29) \\
\end{array}$ & $\begin{array}{l}-0.375 \\
(-4.89) \\
\end{array}$ & $\begin{array}{r}-0.483 \\
(-3.98) \\
\end{array}$ & $\begin{array}{l}-0.448 \\
(-4.04) \\
\end{array}$ & $\begin{array}{r}-0.171 \\
(-1.73) \\
\end{array}$ & $\begin{array}{l}-0.234 \\
(-2.34) \\
\end{array}$ \\
\hline$|\triangle \alpha| /|\alpha|$ & 0.497 & 0.417 & 0.312 & 0.232 & 0.475 & 0.330 \\
\hline $\operatorname{Adj}-R^{2}$ & 0.842 & 0.845 & 0.813 & 0.815 & 0.814 & 0.816 \\
\hline
\end{tabular}




\section{Table 9 : Equity Issuers and Matching Nonissuers' Investment-to-Asset and Profitability in Calendar Time (1970 to 2003)}

This table reports equity issuers and matching nonissuers' investment-to-asset ratios and profitability in calendar time from 1970 to 2003 . We report the median values of these two characteristics for the issuers and matching nonissuer portfolios in the fiscal yearend prior to SEO. We also report the $Z$-statistics associated with the Wilcoxon test for differences in distributions. The null hypothesis is that the characteristics of issuers and nonissuers are both drawn from the same distribution. We measure profitability as net income before extraordinary items (Compustat item 18) divided by lagged book value of assets (item 6). We measure investment-to-asset as the change in gross property, plant, and equipment (item 7) divided by book assets.

\begin{tabular}{|c|c|c|c|c|c|c|}
\hline \multirow[t]{2}{*}{ Year } & \multicolumn{3}{|c|}{ Panel A: Investment-to-asset } & \multicolumn{3}{|c|}{ Panel B: Profitability } \\
\hline & issuers & $\begin{array}{r}\text { non- } \\
\text { issuers }\end{array}$ & $Z$ & issuers & $\begin{array}{l}\text { non- } \\
\text { issuers }\end{array}$ & $Z$ \\
\hline 1970 & 0.130 & 0.086 & 4.71 & 0.138 & 0.136 & 2.14 \\
\hline 1971 & 0.111 & 0.074 & 5.39 & 0.158 & 0.142 & 2.78 \\
\hline 1972 & 0.097 & 0.053 & 7.54 & 0.134 & 0.126 & 2.84 \\
\hline 1973 & 0.131 & 0.047 & 7.65 & 0.137 & 0.112 & 3.33 \\
\hline 1974 & 0.140 & 0.054 & 6.27 & 0.139 & 0.122 & 2.97 \\
\hline 1975 & 0.124 & 0.062 & 8.03 & 0.140 & 0.145 & 1.20 \\
\hline 1976 & 0.100 & 0.056 & 7.63 & 0.133 & 0.146 & 1.18 \\
\hline 1977 & 0.107 & 0.049 & 7.06 & 0.129 & 0.129 & 1.00 \\
\hline 1978 & 0.116 & 0.052 & 8.14 & 0.153 & 0.146 & 2.52 \\
\hline 1979 & 0.139 & 0.063 & 7.78 & 0.144 & 0.142 & 0.63 \\
\hline 1980 & 0.131 & 0.071 & 9.08 & 0.158 & 0.181 & 1.62 \\
\hline 1981 & 0.123 & 0.068 & 8.62 & 0.143 & 0.167 & 0.45 \\
\hline 1982 & 0.103 & 0.072 & 5.71 & 0.144 & 0.147 & 2.84 \\
\hline 1983 & 0.078 & 0.066 & 5.40 & 0.136 & 0.135 & 1.90 \\
\hline 1984 & 0.079 & 0.052 & 4.28 & 0.129 & 0.103 & 2.35 \\
\hline 1985 & 0.109 & 0.071 & 6.72 & 0.172 & 0.117 & 5.22 \\
\hline 1986 & 0.081 & 0.060 & 4.61 & 0.154 & 0.104 & 4.10 \\
\hline 1987 & 0.089 & 0.057 & 3.88 & 0.119 & 0.087 & 0.10 \\
\hline 1988 & 0.089 & 0.054 & 3.81 & 0.130 & 0.088 & 2.13 \\
\hline 1989 & 0.103 & 0.050 & 6.10 & 0.126 & 0.088 & 3.26 \\
\hline 1990 & 0.078 & 0.050 & 3.29 & 0.130 & 0.096 & 1.31 \\
\hline 1991 & 0.084 & 0.050 & 5.88 & 0.112 & 0.106 & -0.35 \\
\hline 1992 & 0.069 & 0.042 & 5.09 & 0.093 & 0.089 & 0.63 \\
\hline 1993 & 0.058 & 0.043 & 6.16 & 0.102 & 0.090 & 1.57 \\
\hline 1994 & 0.059 & 0.047 & 4.46 & 0.103 & 0.107 & -1.04 \\
\hline 1995 & 0.078 & 0.054 & 6.29 & 0.118 & 0.110 & -0.43 \\
\hline 1996 & 0.074 & 0.055 & 5.65 & 0.094 & 0.105 & -2.04 \\
\hline 1997 & 0.106 & 0.061 & 7.82 & 0.132 & 0.121 & 0.74 \\
\hline 1998 & 0.077 & 0.057 & 5.11 & 0.117 & 0.109 & -0.09 \\
\hline 1999 & 0.104 & 0.052 & 6.96 & 0.110 & 0.139 & -2.49 \\
\hline 2000 & 0.105 & 0.054 & 7.29 & 0.066 & 0.130 & -3.37 \\
\hline 2001 & 0.058 & 0.055 & 3.72 & 0.102 & 0.139 & -2.37 \\
\hline 2002 & 0.062 & 0.042 & 5.13 & 0.110 & 0.093 & 2.32 \\
\hline 2003 & 0.027 & 0.024 & 3.76 & 0.047 & 0.059 & -3.18 \\
\hline All & 0.090 & 0.054 & 36.09 & 0.129 & 0.128 & 1.96 \\
\hline
\end{tabular}


Table 10 : Cross-Sectional Tests of the Over-Investment Hypothesis by Splitting the Sample Based on the Gompers-Ishii-Metrick (2003) Governance Index (January 1990 to December 2003) and on the Bebchuk-Cohen-Ferrell (2005) Entrenchment Index (January 1991 to December 2003)

This table reports cross-sectional regression tests of the over-investment hypothesis performed by splitting the sample based on the Gompers-Ishii-Metrick (2003) corporate governance $(G)$ index (Panels A and B) and on the Bebchuk-Cohen-Ferrell (2005) entrenchment $(E)$ index (Panels C and D). Panels A and B are based on the intersection of our sample and that used by Gompers et al. that goes from 1990 to 2003. We split the joint sample into two: the sample with strong shareholder rights contains firms with governance index values less than or equal to nine $(G \leq 9)$ and the sample with weak shareholder rights contains firms with governance index values greater than or equal to ten $(G \geq 10)$. Panels A and B report Fama-MacBeth (1973) cross-sectional regressions of returns onto size, book-to-market, and investment-to-asset ratios in the samples with $G \leq 9$ and $G \geq 10$, respectively. Panels $\mathrm{C}$ and D are based on the intersection of our sample and that used by Bebchuk et al. that goes from 1991 to 2003. We split the joint sample into two subsamples: the low-entrenchment sample contains firms with entrenchment index values less than or equal to two $(E \leq 2)$ and the high-entrenchment sample contains firms with entrenchment index values greater than or equal to three $(E \geq 3)$. Panels C and D report Fama-MacBeth (1973) cross-sectional regressions of returns onto size, book-to-market, and investment-to-asset ratios in the low-entrenchment and high-entrenchment samples, respectively.

\begin{tabular}{|c|c|c|c|c|c|}
\hline \multicolumn{3}{|c|}{ Panel A: Strong shareholder rights $(G \leq 9)$} & \multicolumn{3}{|c|}{ Panel B: Weak shareholder rights $(G \geq 10)$} \\
\hline $\log (\mathrm{ME})$ & $\log (\mathrm{BE} / \mathrm{ME})$ & investment-to-asset & $\log (\mathrm{ME})$ & $\log (\mathrm{BE} / \mathrm{ME})$ & investment-to-asset \\
\hline & & $\begin{array}{l}-1.308 \\
(-3.03)\end{array}$ & & & $\begin{array}{l}-0.789 \\
(-2.83)\end{array}$ \\
\hline $\begin{array}{l}-0.180 \\
(-1.90) \\
\end{array}$ & $\begin{array}{l}-0.059 \\
(-0.35) \\
\end{array}$ & $\begin{array}{l}-0.941 \\
(-2.41) \\
\end{array}$ & $\begin{array}{l}-0.129 \\
(-1.52) \\
\end{array}$ & $\begin{array}{l}-0.035 \\
(-0.26) \\
\end{array}$ & $\begin{array}{l}-0.443 \\
(-1.56) \\
\end{array}$ \\
\hline \multicolumn{3}{|c|}{ Panel C: Low entrenchment $(E \leq 2)$} & \multicolumn{3}{|c|}{ Panel D: High entrenchment $(E \geq 3)$} \\
\hline $\log (\mathrm{ME})$ & $\log (\mathrm{BE} / \mathrm{ME})$ & investment-to-asset & $\log (\mathrm{ME})$ & $\log (\mathrm{BE} / \mathrm{ME})$ & investment-to-asset \\
\hline & & $\begin{array}{l}-0.907 \\
(-2.32)\end{array}$ & & & $\begin{array}{l}-0.729 \\
(-1.86)\end{array}$ \\
\hline $\begin{array}{l}-0.188 \\
(-1.96)\end{array}$ & $\begin{array}{l}-0.153 \\
(-0.85)\end{array}$ & $\begin{array}{l}-0.597 \\
(-1.73)\end{array}$ & $\begin{array}{l}-0.154 \\
(-1.68)\end{array}$ & $\begin{array}{l}0.116 \\
(0.83)\end{array}$ & $\begin{array}{l}-0.202 \\
(-0.55)\end{array}$ \\
\hline
\end{tabular}


Table 11 : SEOs and Matching Firms' Corporate Governance Index (1990 to 2003) and Entrenchment Index (1991 to 2003) in Calendar Time

Panels A and B of this table report issuers' and matching nonissuers' median and mean Governance indexes based on Gompers, Ishii, and Metrick (2003) in calendar time from 1990 to 2003. Gompers et al. obtain firm-level corporate governance provisions from the Investor Responsibility Research Center (IRRC). The index counts the number of unique provisions each firm, and it ranges from 1 to 24 . We intersect the sample used by Gompers et al. with our sample based on size, book-to-market, and investment-to-asset ratio. Panels $\mathrm{C}$ and $\mathrm{D}$ of this table report issuers' and matching nonissuers' median and mean entrenchment indexes based on Bebchuk, Cohen, and Ferrell (2005) in calendar time from 1991 to 2003. Bebchuk et al. construct their index based on six out of 24 provisions from the IRRC. The six provisions include staggered boards, limits to shareholder bylaw amendments, supermajority requirements for mergers, supermajority requirements for charter amendments, poison pills, and golden parachutes. The entrenchment index counts the number of unique provisions each firm has in the sample, and it ranges from 0 to 6 . We intersect the sample used by Bebchuk et al. with our sample based on size, book-to-market, and investment-to-asset. In Panels A and C we also report $Z$-statistics from the Wilcoxon matched-pairs signed-rank test for differences in distributions. The null hypothesis is that the characteristics of issuers and nonissuers are both drawn from the same distribution. In Panels B and D we report $t$-statistics for the differences in means.

\begin{tabular}{|c|c|c|c|c|c|c|}
\hline \multirow[b]{2}{*}{ Year } & \multicolumn{3}{|c|}{ Panel A: Median governance index } & \multicolumn{3}{|c|}{ Panel B: Mean governance index } \\
\hline & issuers & non-issuers & $Z$ & issuers & non-issuers & $t$ \\
\hline 1990 & 9 & 8 & -0.35 & 8.926 & 9.009 & -0.15 \\
\hline 1991 & 9 & 8 & -2.05 & 8.881 & 9.334 & -1.49 \\
\hline 1992 & 9 & 8 & -1.08 & 8.903 & 9.247 & -0.86 \\
\hline 1993 & 9 & 9 & -0.61 & 9.367 & 9.377 & -0.03 \\
\hline 1994 & 9 & 9 & -1.17 & 8.854 & 9.245 & -0.87 \\
\hline 1995 & 8 & 9 & -3.55 & 8.175 & 9.490 & -3.53 \\
\hline 1996 & 9 & 9 & -0.79 & 9.333 & 9.322 & 0.03 \\
\hline 1997 & 8.5 & 9 & -2.29 & 8.946 & 9.508 & -1.51 \\
\hline 1998 & 8 & 8 & -2.19 & 8.313 & 9.092 & -2.05 \\
\hline 1999 & 8 & 8.5 & -3.16 & 8.073 & 9.250 & -3.22 \\
\hline 2000 & 8 & 9 & -3.29 & 8.085 & 9.303 & -3.20 \\
\hline 2001 & 10 & 9 & 0.48 & 9.070 & 9.332 & -0.62 \\
\hline 2002 & 9 & 9 & -1.03 & 9.315 & 9.359 & -0.16 \\
\hline 2003 & 9 & 9 & -1.43 & 9.274 & 9.451 & -0.53 \\
\hline \multirow[t]{2}{*}{ All } & 9 & 9 & -6.09 & 8.847 & 9.320 & -4.78 \\
\hline & \multicolumn{3}{|c|}{ Panel C: Median entrenchment index } & \multicolumn{3}{|c|}{ Panel D: Mean entrenchment index } \\
\hline Year & issuers & non-issuers & $Z$ & issuers & non-issuers & $t$ \\
\hline 1991 & 3 & 2 & 0.38 & 2.387 & 2.312 & 0.32 \\
\hline 1992 & 2 & 2 & -0.19 & 2.297 & 2.273 & 0.14 \\
\hline 1993 & 2 & 2 & -1.91 & 2.188 & 2.276 & -0.69 \\
\hline 1994 & 3 & 2 & -0.01 & 2.317 & 2.286 & 0.16 \\
\hline 1995 & 2 & 2 & -2.01 & 2.091 & 2.392 & -1.51 \\
\hline 1996 & 2 & 2 & -1.58 & 2.104 & 2.355 & -1.22 \\
\hline 1997 & 2 & 2 & -1.99 & 2.024 & 2.388 & -2.03 \\
\hline 1998 & 2 & 2 & -1.77 & 2.081 & 2.316 & -1.03 \\
\hline 1999 & 2 & 2 & -1.54 & 2.000 & 2.304 & -1.32 \\
\hline 2000 & 2 & 2 & -2.80 & 1.750 & 2.232 & -2.56 \\
\hline 2001 & 3 & 2 & 1.35 & 2.635 & 2.317 & 1.64 \\
\hline 2002 & 3 & 3 & -0.49 & 2.562 & 2.48 & 0.60 \\
\hline 2003 & 3 & 3 & -0.21 & 2.580 & 2.47 & 0.73 \\
\hline$\overline{\text { All }}$ & 2 & 2 & -3.26 & 2.261 & 2.344 & -1.66 \\
\hline
\end{tabular}




\section{Table 12 : SEOs and Matching Firms' Market Leverage and Book Leverage in Calendar Time (1970 to 2003)}

This table reports SEOs and matching firms' market leverage and book leverage ratios in calendar time from 1970 to 2003 . We report the median values of these two characteristics for the issuers and matching nonissuer portfolios, as well as the $Z$-statistics associated with the Wilcoxon test for differences in distributions. The null hypothesis is that the characteristics of issuers and nonissuers are both drawn from the same distribution. We measure market leverage as the sum of debt in current liabilities (item 9) and long-term debt (item 34) divided by the sum of the market value of equity at the calendar year end and the book value of debt (item 9 plus item 34). We measure book leverage as the sum of item 9 plus item 34 divided by item 6 .

\begin{tabular}{|c|c|c|c|c|c|c|}
\hline \multirow[t]{2}{*}{ Year } & \multicolumn{3}{|c|}{ Panel A: Market leverage } & \multicolumn{3}{|c|}{ Panel B: Book leverage } \\
\hline & issuers & $\begin{array}{r}\text { non- } \\
\text { issuers }\end{array}$ & $Z$ & issuers & $\begin{array}{r}\text { non- } \\
\text { issuers }\end{array}$ & $Z$ \\
\hline 1970 & 0.441 & 0.291 & 3.97 & 0.562 & 0.318 & 5.35 \\
\hline 1971 & 0.266 & 0.264 & 4.58 & 0.429 & 0.295 & 5.84 \\
\hline 1972 & 0.270 & 0.231 & 4.16 & 0.402 & 0.273 & 6.54 \\
\hline 1973 & 0.540 & 0.267 & 6.07 & 0.533 & 0.273 & 6.95 \\
\hline 1974 & 0.683 & 0.471 & 6.32 & 0.575 & 0.297 & 6.77 \\
\hline 1975 & 0.637 & 0.376 & 8.21 & 0.530 & 0.262 & 9.06 \\
\hline 1976 & 0.511 & 0.301 & 5.99 & 0.473 & 0.255 & 7.58 \\
\hline 1977 & 0.582 & 0.312 & 7.29 & 0.501 & 0.262 & 7.90 \\
\hline 1978 & 0.538 & 0.304 & 7.74 & 0.484 & 0.264 & 8.37 \\
\hline 1979 & 0.535 & 0.308 & 7.31 & 0.482 & 0.273 & 8.23 \\
\hline 1980 & 0.270 & 0.204 & 6.42 & 0.451 & 0.262 & 8.80 \\
\hline 1981 & 0.342 & 0.231 & 7.01 & 0.444 & 0.260 & 8.64 \\
\hline 1982 & 0.342 & 0.318 & 5.55 & 0.379 & 0.235 & 8.27 \\
\hline 1983 & 0.230 & 0.193 & 4.79 & 0.303 & 0.233 & 8.52 \\
\hline 1984 & 0.243 & 0.258 & 2.26 & 0.313 & 0.236 & 4.09 \\
\hline 1985 & 0.187 & 0.159 & 2.59 & 0.326 & 0.248 & 4.76 \\
\hline 1986 & 0.187 & 0.143 & 3.09 & 0.297 & 0.242 & 4.25 \\
\hline 1987 & 0.244 & 0.199 & 3.05 & 0.314 & 0.253 & 3.99 \\
\hline 1988 & 0.272 & 0.178 & 2.47 & 0.384 & 0.256 & 3.77 \\
\hline 1989 & 0.200 & 0.217 & 1.30 & 0.385 & 0.252 & 4.10 \\
\hline 1990 & 0.186 & 0.197 & 0.45 & 0.341 & 0.239 & 2.95 \\
\hline 1991 & 0.183 & 0.182 & 1.43 & 0.322 & 0.222 & 5.09 \\
\hline 1992 & 0.240 & 0.176 & 4.02 & 0.343 & 0.211 & 6.90 \\
\hline 1993 & 0.178 & 0.156 & 4.85 & 0.295 & 0.195 & 7.56 \\
\hline 1994 & 0.106 & 0.106 & 1.63 & 0.235 & 0.182 & 4.05 \\
\hline 1995 & 0.083 & 0.116 & 0.94 & 0.240 & 0.191 & 4.76 \\
\hline 1996 & 0.096 & 0.119 & 2.62 & 0.276 & 0.192 & 7.09 \\
\hline 1997 & 0.114 & 0.078 & 4.28 & 0.309 & 0.174 & 8.05 \\
\hline 1998 & 0.180 & 0.129 & 6.26 & 0.385 & 0.181 & 8.64 \\
\hline 1999 & 0.103 & 0.065 & 2.47 & 0.295 & 0.201 & 6.50 \\
\hline 2000 & 0.029 & 0.074 & -2.47 & 0.164 & 0.186 & 3.44 \\
\hline 2001 & 0.135 & 0.107 & 3.94 & 0.288 & 0.180 & 6.70 \\
\hline 2002 & 0.299 & 0.177 & 6.86 & 0.365 & 0.186 & 8.19 \\
\hline 2003 & 0.250 & 0.060 & 2.66 & 0.273 & 0.083 & 3.47 \\
\hline All & 0.220 & 0.193 & 16.96 & 0.358 & 0.208 & 38.89 \\
\hline
\end{tabular}


Figure 1. The Investment Hypothesis of Underperformance Following Seasoned Equity Offerings

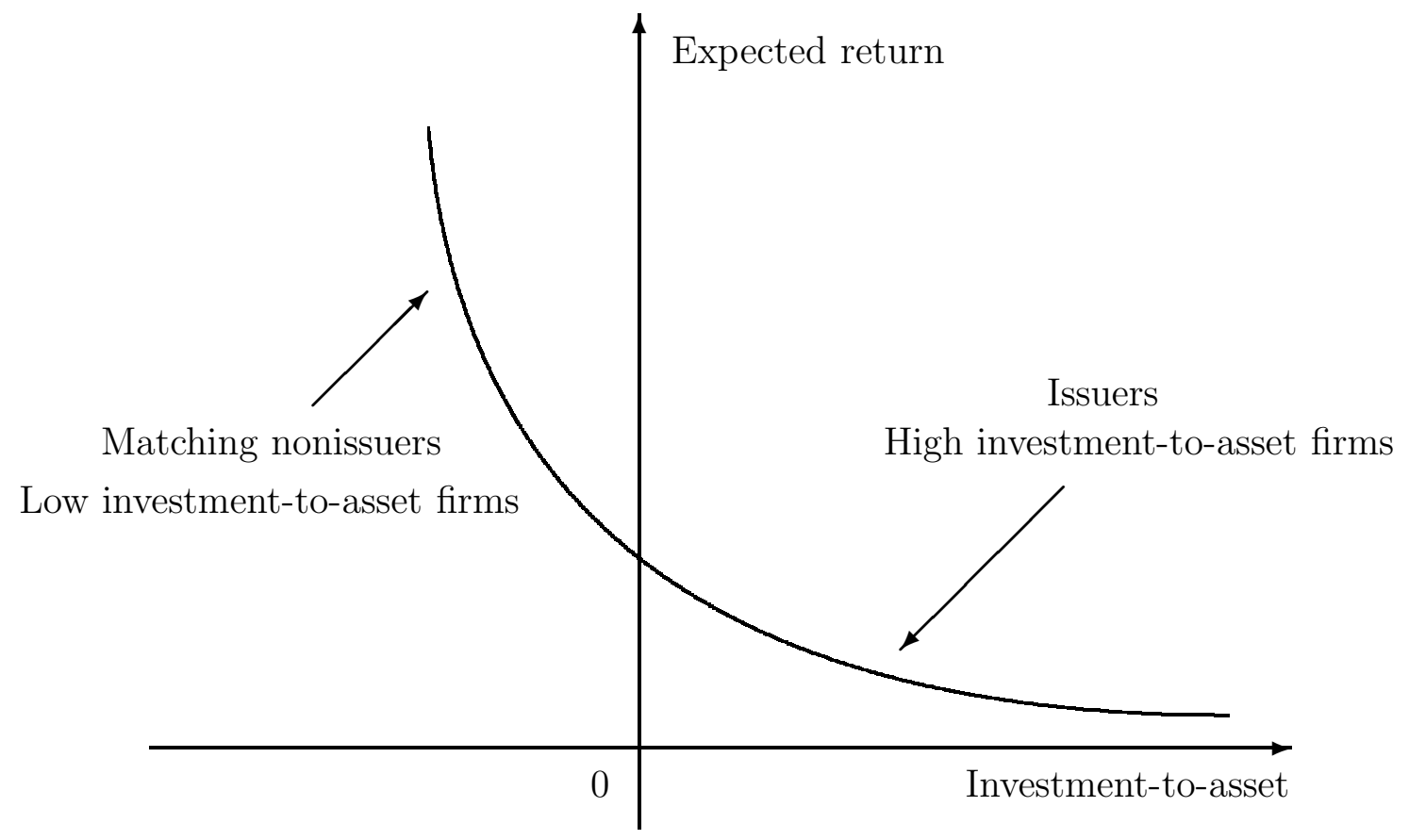


Figure 2 : The Frequency Distribution and New Equity-to-Asset Ratio of SEO Firms Across Size and Book-to-Market Quintiles (January 1970 to December 2003)

Panel A of this figure plots the number of SEO firms in each of the 25 size and book-to-market portfolios. Panel B reports the median new equityto-asset ratio among equity issuers by size and book-to-market quintiles. We measure book assets as Compustat annual item 6 . We calculate size as the price at the end of June times the number of shares outstanding. We define book equity as stockholder's equity (item 216), minus preferred stock, plus balance sheet deferred taxes and investment tax credit (item 35) if available, minus post-retirement benefit asset (item 330) if available. If stockholder's equity is missing, we use common equity (item 60) plus preferred stock par value (item 130). If these variables are missing, we use book assets (item 6) less liabilities (item 181). We measure preferred stock as preferred stock liquidating value (item 10), or preferred stock redemption value (item 56), or preferred stock par value (item 130), in that order of availability. To calculate the book-to-market ratio, we use the market size at the end of the fiscal year, which is December closing price times the number of shares outstanding. We obtain the size and book-to-market quintile breakpoints from Kenneth French's website. We measure new equity-to-asset as the market value of new equity (obtained from SDC) divided by the book value of assets at the end of the fiscal year preceding the equity issue.

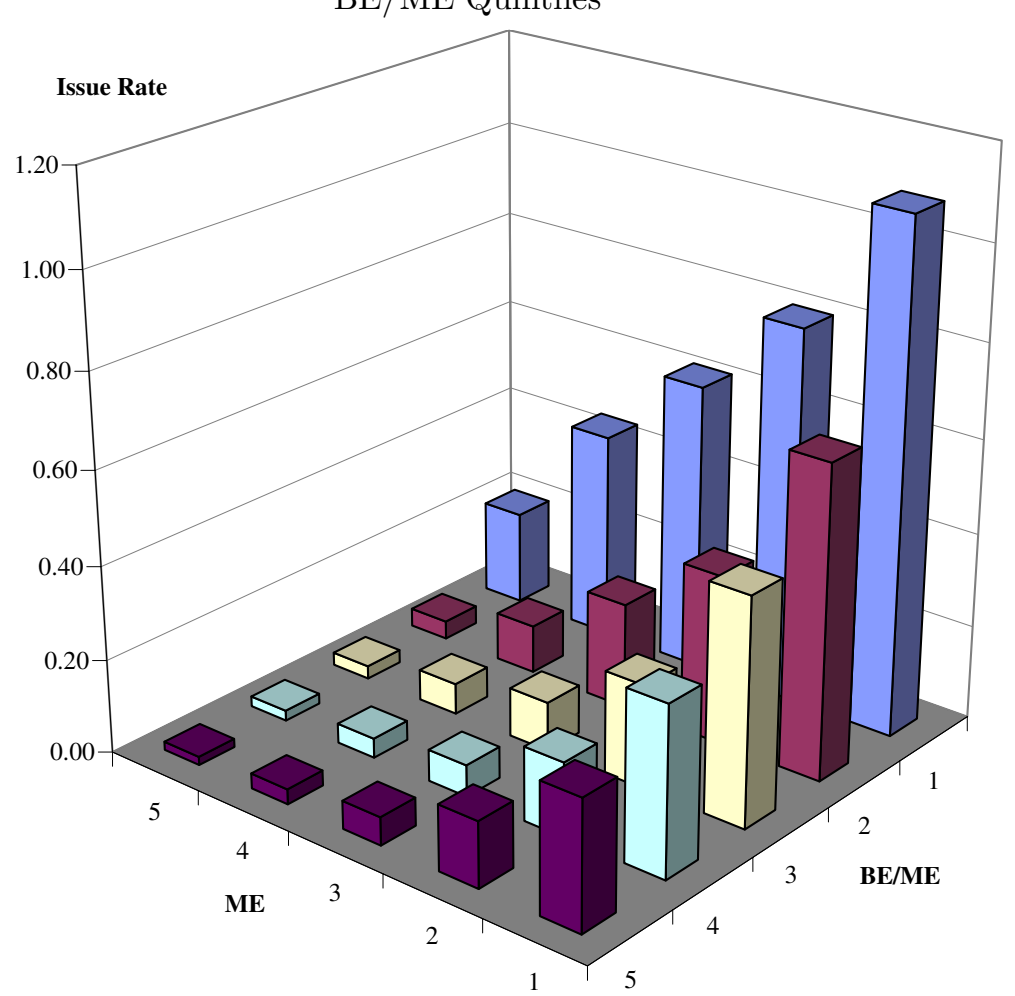


Figure 3 : Equity Issuers' and Matching Nonissuers' Investment-to-Asset and Profitability During 60 Months After Equity Issuance (January 1970 to December 2003)

This figure plots SEO firms' and matching nonissuers' median investment-to-asset ratio and profitability during 60 months after equity issuance in Panels $\mathrm{A}$ and $\mathrm{C}$, as well as their corresponding $Z$-statistics from the Wilcoxon test for testing distributional differences in Panels $\mathrm{B}$ and $\mathrm{D}$, respectively. $Z$ statistics between -2 and 2 indicate failure to reject the null hypothesis of equal distribution of characteristics between SEOs and their matching firms. Month 0 is the month of equity issuance. We measure investment-to-asset ratio as the ratio of the change in gross property, plant, and equipment (Compustat item 7) and lagged book assets (item 6). Profitability is defined as net income before extraordinary items (item 18) divided by lagged book assets. The solid lines are for issuers and the broken lines are for matching nonissuers. We use the following matching procedure. At the end of June every year, all firms that have not issued equity within the prior 36 months are sorted by their size and book-to-market equity to form 25 size and book-to-market portfolios of nonissuers. For each issuer, we use the breakpoints of size and book-to-market sort to identify its matching portfolio. The matching portfolio's median characteristics are then compared with those of the issuer.
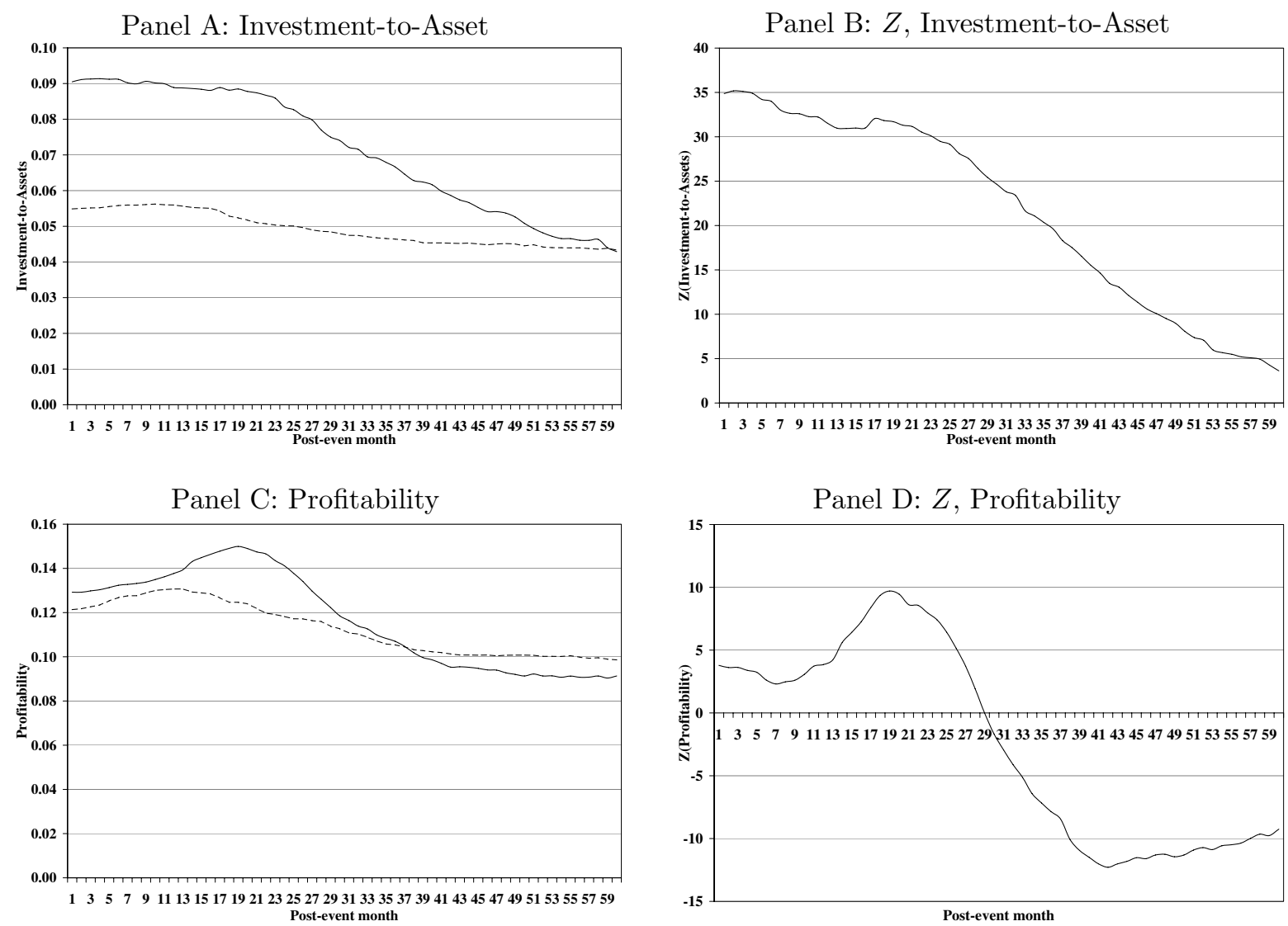


\section{Figure 4 : The Frequency Distribution of SEOs across Investment-to-Asset Deciles (January 1970 to December 2003)}

This figure plots the number of SEO firms in each of the investment-to-asset deciles. We measure book assets as Compustat annual item 6, and we measure capital investment as the change in item 7 (gross property, plant, and equipment). We sort nonissuing firms each year by their investment-to-asset ratios to obtain the decile breakpoints. We then assign each SEO firm to one of the investment-to-asset deciles based on the breakpoints.

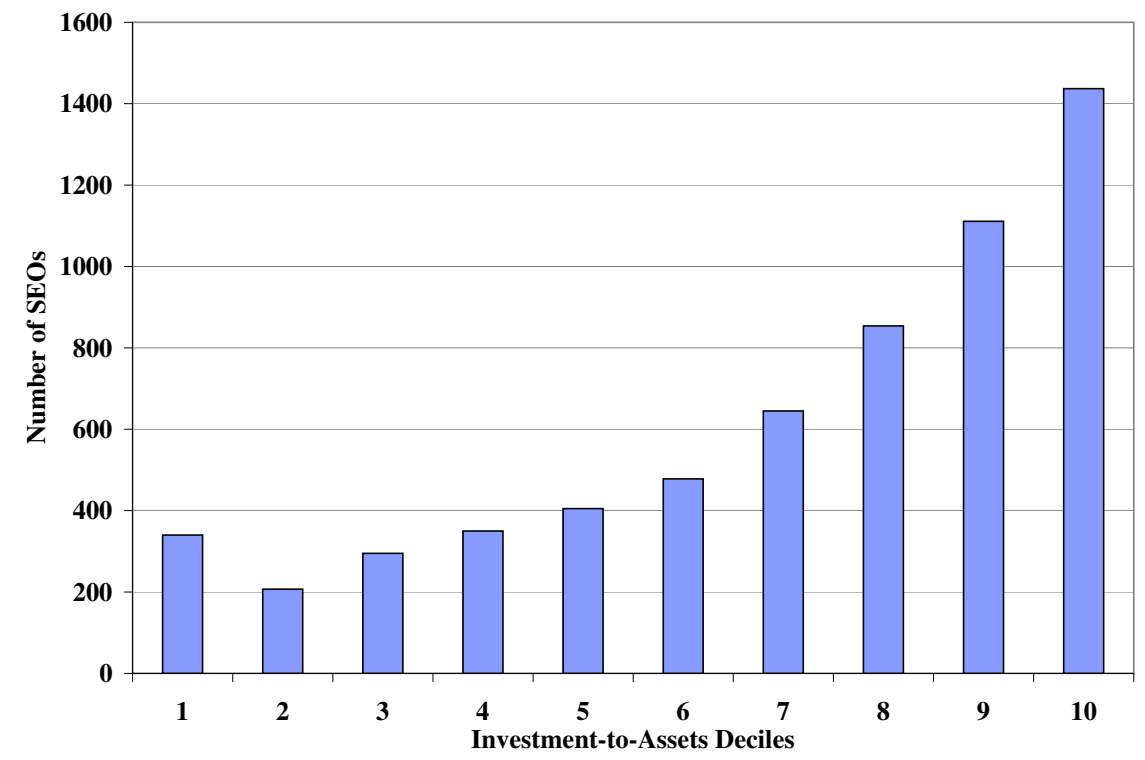




\section{Figure 5 : SEO Firms' and Matching Firms' Corporate Governance Indexes During 60 Months After Equity Issuance (January 1990 to December 2003)}

This figure plots SEO firms' (solid lines) and matching firms' (dotted lines) median and mean corporate governance indices as defined by Gompers, Ishii, and Metrick (2003) during 60 months after equity issuance in Panels A and C, respectively. We also report in Panel B the $Z$-statistics from the Wilcoxon matchedpairs signed-rank test for distributional differences in the median indices between issuers and nonissuers. $Z$ statistics between -2 and 2 indicate failure to reject the null hypothesis of equal distribution of characteristics between issuers and nonissuers. Panel D reports the $t$-statistics for zero-difference between the mean indices between the two classes of firms. Month 0 is the month of equity issuance. Gompers et al. obtain firm-level corporate governance provisions from the Investor Responsibility Research Center (IRRC). The index counts the number of unique provisions each firm has in the sample, and it ranges from 1 to 24 . We use the following matching procedure. At the end of June every year, all firms that have not issued equity within the prior 36 months are sorted by their size and book-to-market equity to form 25 size and book-to-market portfolios of nonissuers. For each issuer, we use the breakpoints of size and book-to-market sort to identify its matching portfolio. The matching portfolio's median and mean characteristics are then compared with those of the issuer.

Panel A: Median Governance Index

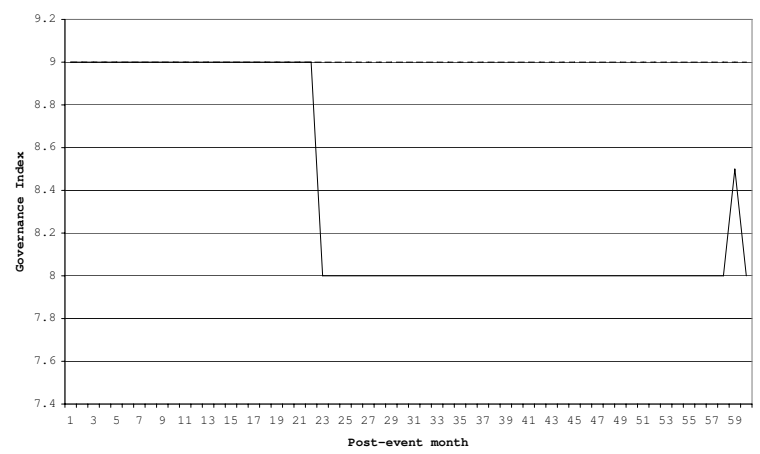

Panel C: Mean Governance Index

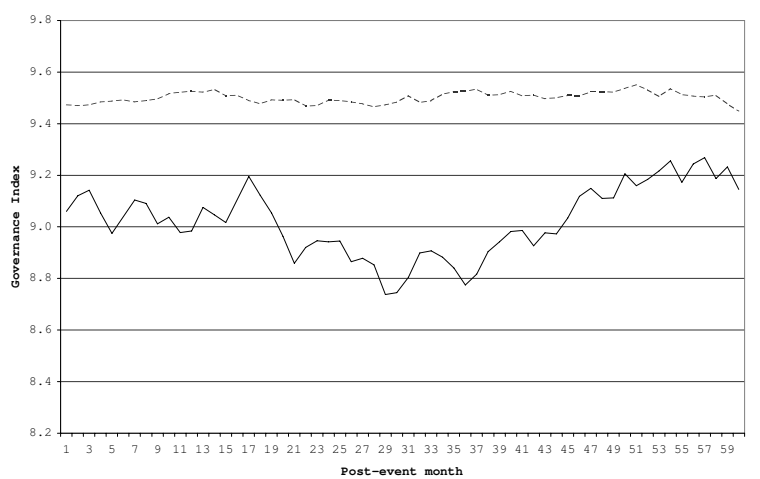

Panel B: $Z$, Median Governance Index

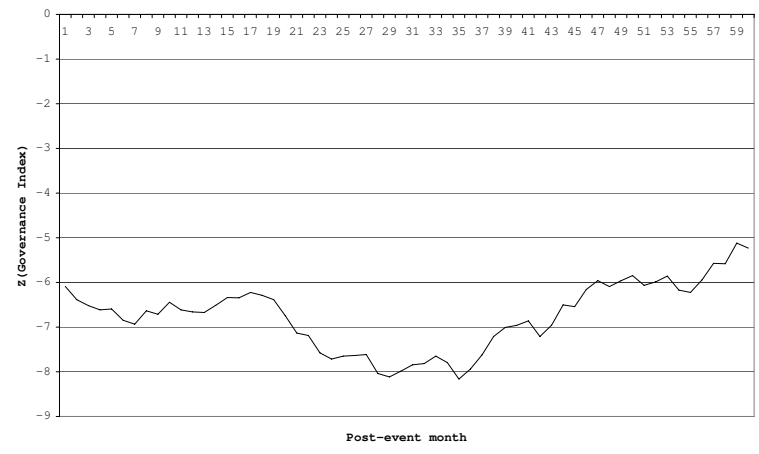

Panel D: $t$, Mean Governance Index

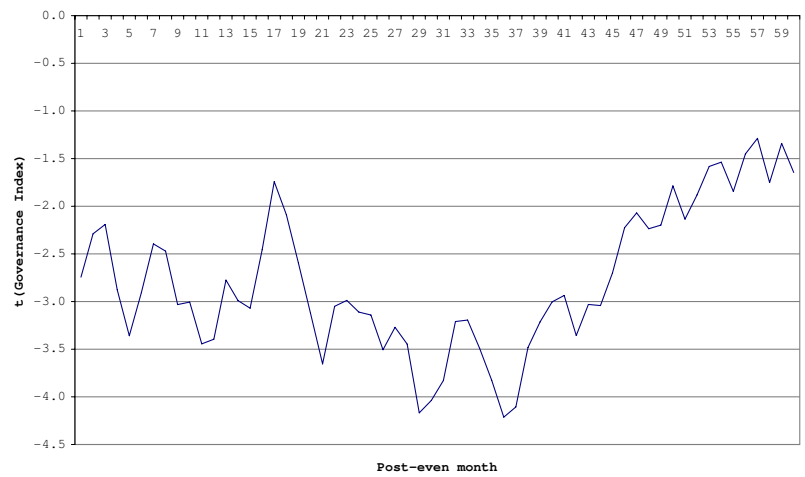




\section{Figure 6 : SEO Firms' and Matching Firms' Entrenchment Indexes During 60 Months After Equity Issuance (January 1991 to December 2003)}

This figure plots SEO firms' (solid lines) and matching firms' (dotted lines) median and mean entrenchment indexes as defined by Bebchuk, Cohen, and Ferrell (2005) during 60 months after equity issuance in Panels A and $\mathrm{C}$, respectively. We also report in Panel B the $Z$-statistics from the Wilcoxon matched-pairs signed-rank test for distributional differences in the median indices between issuers and nonissuers. $Z$ statistics between -2 and 2 indicate failure to reject the null hypothesis of equal distribution of characteristics between issuers and nonissuers. Panel D reports the $t$-statistics for zero-difference between the mean indices between the two classes of firms. Month 0 is the month of equity issuance. Bebchuk et al. construct their entrenchment index based on six out of 24 provisions from the Investor Responsibility Research Center (IRRC). The six provisions are staggered boards, limits to shareholder bylaw amendments, supermajority requirements for mergers, supermajority requirements for charter amendments, poison pills, and golden parachutes. The index counts the number of unique provisions each firm has in the sample, and it ranges from 0 to 6 . We use the following matching procedure. At the end of June every year, all firms that have not issued equity within the prior 36 months are sorted by their size and book-to-market equity to form 25 size and book-to-market portfolios of nonissuers. For each issuer, we use the breakpoints of size and book-to-market sort to identify its matching portfolio. The matching portfolio's median and mean characteristics are then compared with those of the issuer.

Panel A: Median Entrenchment Index

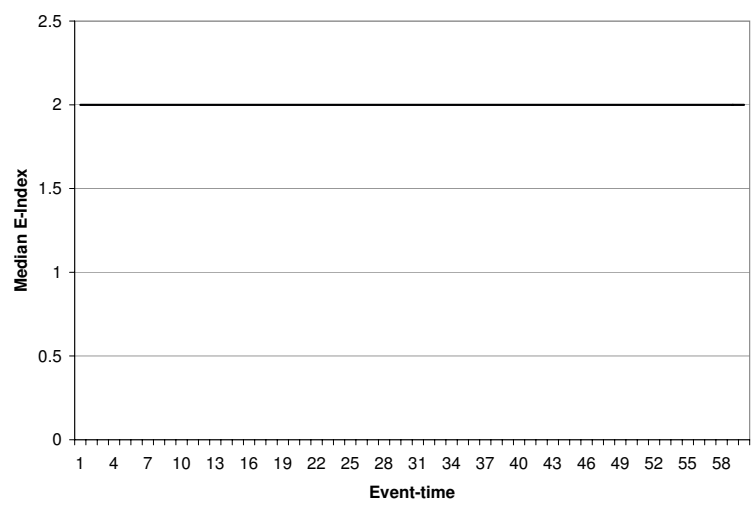

Panel C: Mean Entrenchment Index

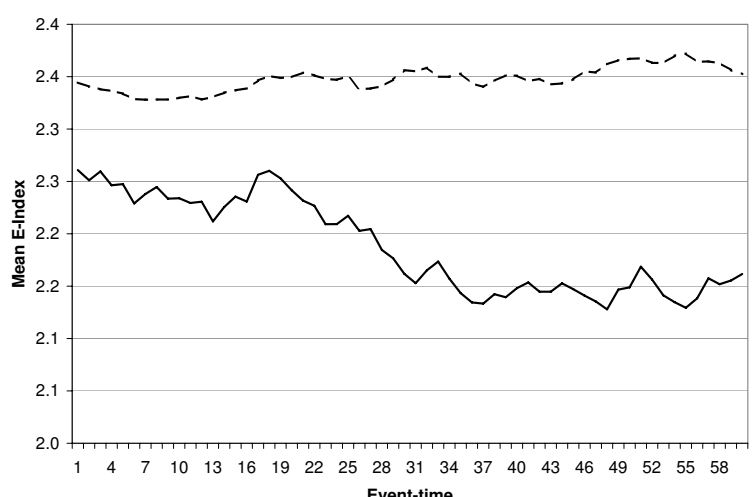

Panel B: Z, Median Entrenchment Index

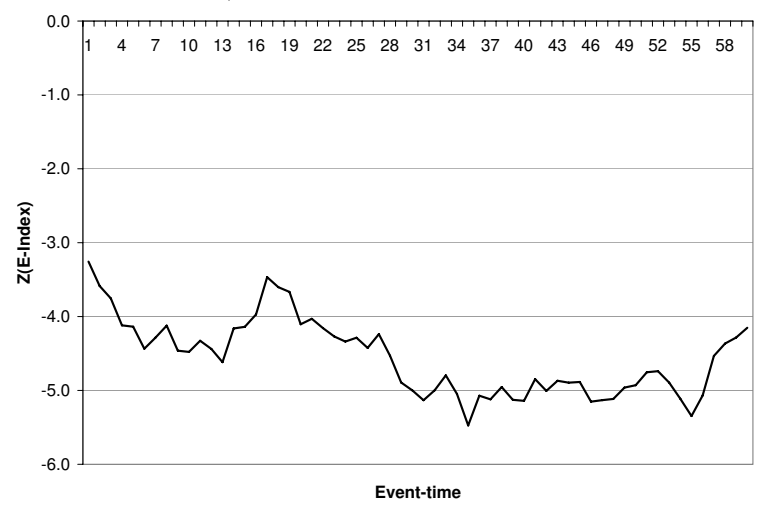

Panel D: $t$, Mean Entrenchment Index

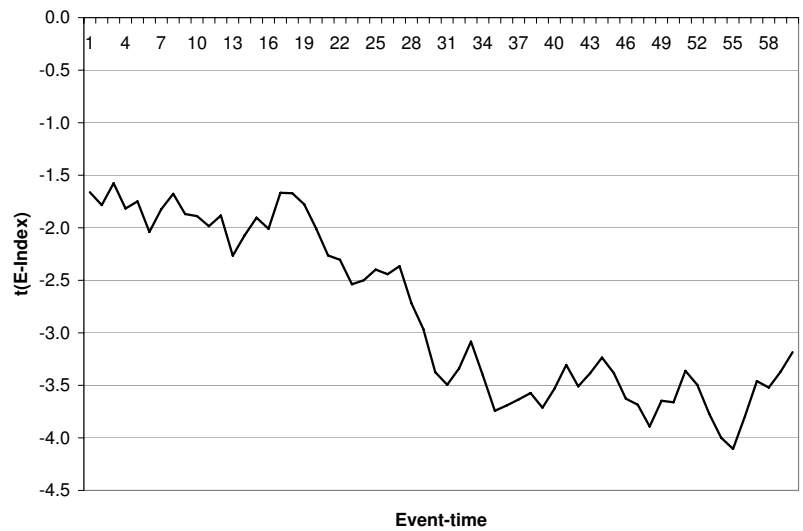




\section{Figure 7 : SEO Firms' and Matching Firms' Market Leverage and Book Leverage During 60 Months After Equity Issuance (1970 to 2003)}

This figure plots issuers' and matching nonissuers' median market leverage ratio and book leverage ratio during 60 months after equity issuance in Panels $\mathrm{A}$ and $\mathrm{C}$, respectively, and their corresponding $Z$-statistics from the Wilcoxon test for testing distributional differences in Panels B and D. $Z$ statistics between -2 and 2 indicate failure to reject the null hypothesis of equal distribution of characteristics between SEOs and their matching firms. Month 0 is the month of equity issuance. We define book leverage as the sum of debt in current liabilities (Compustat annual item 9) and long-term debt (item 34) divided by the lagged book value of assets. The denominator of the market leverage ratio is the market value of the firm, calculated as the sum of the market value of equity (December closing price times number of shares outstanding) and the book value of debt (item 9 plus item 34). The solid lines are for issuers and the broken lines are for matching nonissuers. We use the following matching procedure. At the end of June every year, all firms that have not issued equity within the prior 36 months are sorted by their size and book-to-market equity to form 25 size and book-to-market portfolios of nonissuers. For each issuer, we use the breakpoints of size and book-to-market sort to identify its matching portfolio. The matching portfolio's median characteristics are then compared with those of the issuer.
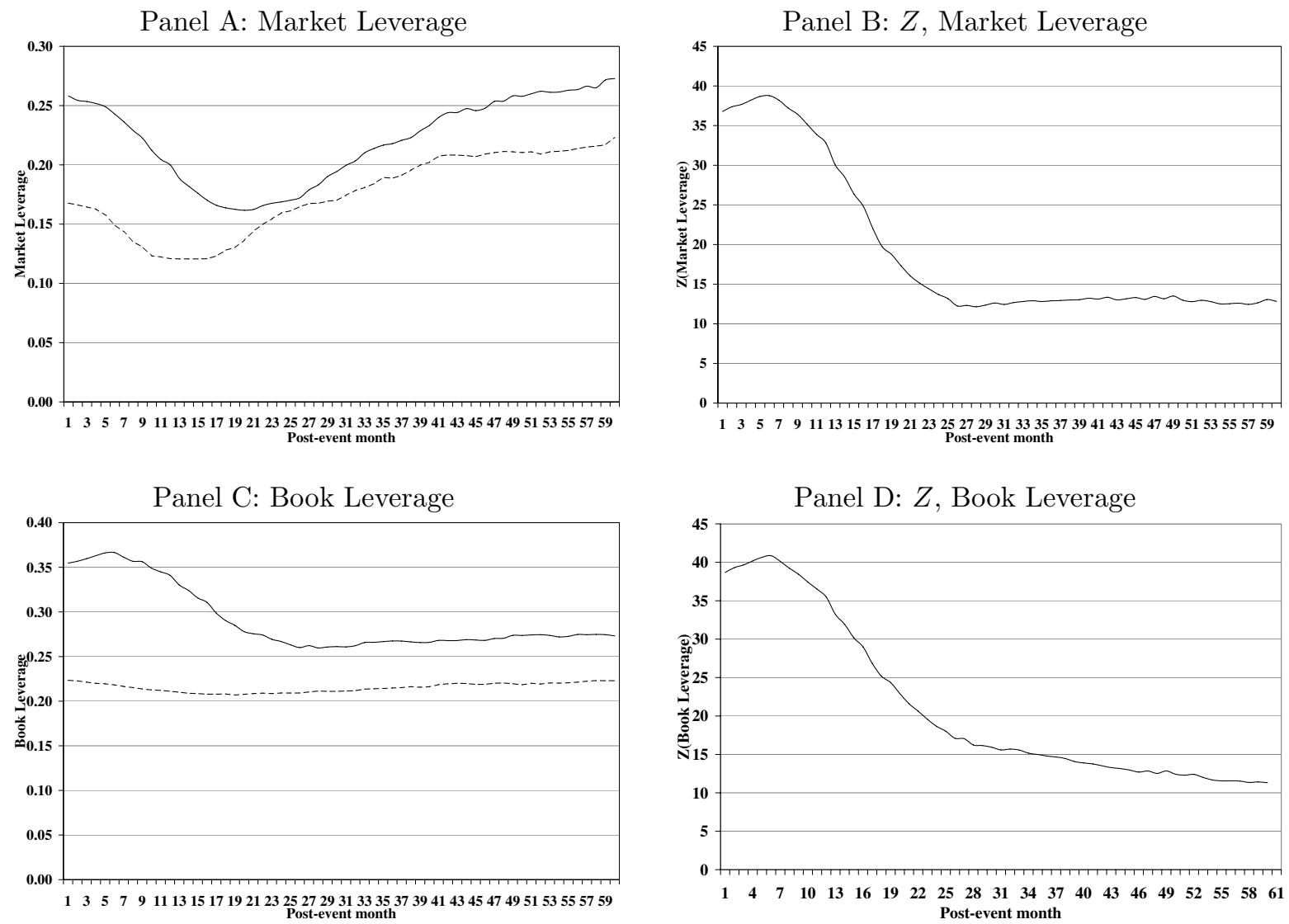